\title{
BODIPY-Based Photoacid Generators (PAGs) for Light-Induced Cationic Polymerization
}

\author{
Karthik Sambath, ${ }^{\ddagger}$ Zhaoxiong Wan ${ }^{\ddagger}$ Qi Wang, Hao Chen, and Yuanwei Zhang* \\ Department of Chemistry and Environment Science, College of Science and Liberal Arts, New Jersey \\ Institute of Technology, 323 Martin Luther King Jr. Blvd., Newark, New Jersey 07102, USA. \\ $\ddagger$ These authors contributed equally.
}

General Experimental section: All reagents and solvents were purchased from commercial suppliers and used without further purification. Compound $\mathbf{1}$ and $\mathbf{3}$ were synthesized according to their previous reported procedures. Heating reactions were performed in silica oil bath. Microwave reactions were performed using microwave reactor (CEM, discover SP) with closed vessel standard mode (maximum temperature $170{ }^{\circ} \mathrm{C}$, maximum pressure $40 \mathrm{psi}$, maximum power $100 \mathrm{~W}$, high speed stirring). ${ }^{1} \mathrm{H}$ and ${ }^{13} \mathrm{C}$ NMR spectra were carried out in $\mathrm{CDCl}_{3}$ solution on a Bruker AVANCE spectrometer $(500 \mathrm{MHz})$. orbitrap mass spectrometry analyses were performed at the Prof. Hao Chen lab, Department of Chemistry and Environmental Science, New jersey institute of technology (NJIT). Flash column chromatography was performed on an Interchim Puriflash and Prep 430 instrument using normalphase HP silica columns. UV-vis absorption spectra were recorded on a Tecan Infinite M200 PRO plate reader spectrometer in $1 \mathrm{~cm}$ path length quartz cuvettes. Fluorescence emission spectra were measured using an FLS980 fluorescence spectrometer. 


\section{Synthesis:}
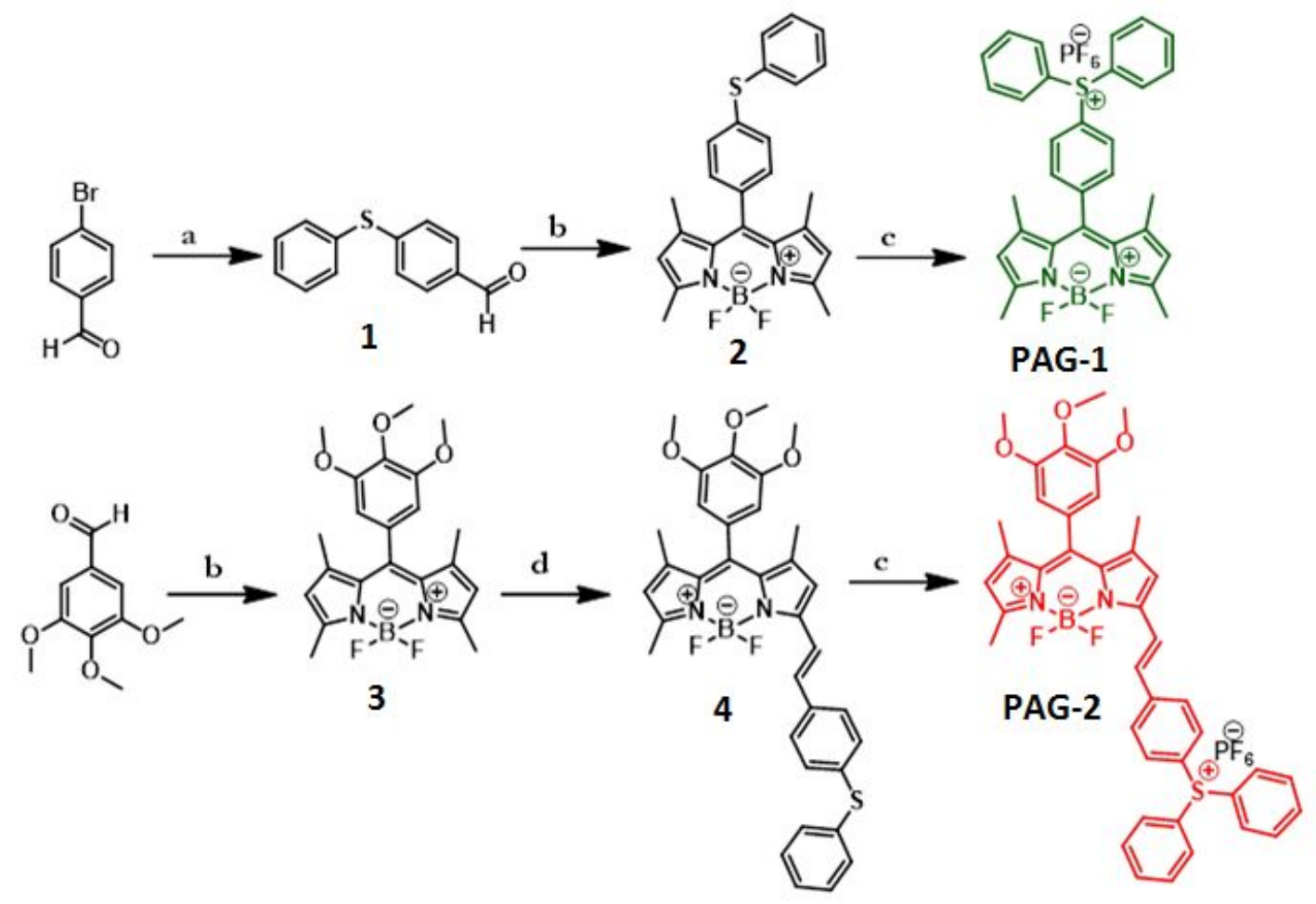

Reagents: a) Thiophenol/ $\mathrm{K}_{2} \mathrm{CO}_{3} / \mathrm{DMF} / \mathrm{CuI} / 120^{\circ} \mathrm{C} / 2$ h; b) 2,4-dimethyl pyrrole/TFA $/ 12 \mathrm{~h} / \mathrm{DDQ} / 4 \mathrm{~h} / \mathrm{DIPEA} / \mathrm{BF}_{3} \cdot \mathrm{OET}_{2}$; c) diphenyliodonium hexa fluoro phospahate / $\mathrm{Cu}(\mathrm{II})$ benzoate /chlorobenzene /microwave irradiation / 5 $\min / 170^{\circ} \mathrm{C} / 40 \mathrm{psi}$; d) Compound 1,Piperidine/acetic acid/DMF/microwave irradiation $/ 5$ $\min / 170^{\circ} \mathrm{C} / 40 \mathrm{psi}$.

Scheme: S1. Synthesis of PAG-1 and PAG-2.

\section{1) Experimental procedure:}

a) Synthesis of 4-(phenylthio)benzaldehyde (1) ${ }^{[1]}$ : A mixture of CuI (50 mg) benzenethiol (1.7 g, $1.5 \mathrm{eq}), \mathrm{K}_{2} \mathrm{CO}_{3}(3.7 \mathrm{~g}, 2.5 \mathrm{eq})$ and dry DMF (10 ml ) was treated with 4-bromo benzaldehyde (2 g, 2 eq) and the resulting mixture was stirred at room temperature to $120^{\circ} \mathrm{C}$ (silica oil bath) for $4 \mathrm{~h}$. The mixture was extracted with ethyl acetate; the obtained organic layer was washed with saturated brine. The resulting organic layer was dried over $\mathrm{Na}_{2} \mathrm{SO}_{4}$. The crude product was further purified by column chromatography (silica gel: hexane/ ethyl acetate, 90:10) to give 2.3 g pale yellow solid (70\% isolated

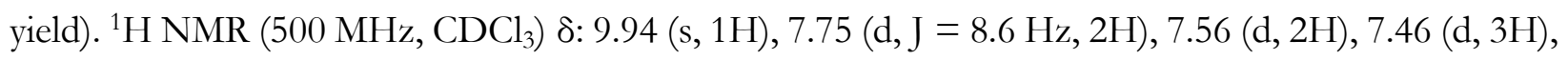
$7.27(\mathrm{~d}, \mathrm{~J}=8.6 \mathrm{~Hz}, 2 \mathrm{H}) ;{ }^{13} \mathrm{C}$ NMR $\left(126 \mathrm{MHz}, \mathrm{CDCl}_{3}\right)$ 8: 191.1, 147.2, 134.3, 133.7, 131.3, 130.1, 129.8, 129.2, 127.2. 
b) Synthesis of 4-(phenylthio) BODIPY (2): Trifluoroacetic acid ( $25 \mu \mathrm{L}, 0.33 \mathrm{mmol})$ in $\operatorname{dry~} \mathrm{CH}_{2} \mathrm{Cl}_{2}$ $(15 \mathrm{~mL})$ was added drop wise to a solution of 4-(phenylthio)benzaldehyde (1 g, $2.5 \mathrm{mmol})$ and 2,4dimethyl-1H-pyrrole $(0.74 \mathrm{~mL}, 2.5 \mathrm{mmol})$ in dry $\mathrm{CH}_{2} \mathrm{Cl}_{2}(15 \mathrm{~mL})$ at room temperature. The reaction mixture was stirred for 3 hours at room temperature, 2, 3-Dichloro-5, 6-dicyano-1, 4-benzoquinone $(1.58 \mathrm{~g}, 2.5 \mathrm{mmol})$ was added under ice bath cooling and the mixture was stirred for $30 \mathrm{~min}$. After stirring for an additional 1 hour at room temperature, diisopropyl ethylamine (DIPEA) (5 mL, 36 $\mathrm{mmol}$ ) was added, followed by slow addition of $\mathrm{BF}_{3}-\mathrm{Et}_{2} \mathrm{O}(5 \mathrm{~mL}, 40.5 \mathrm{mmol})$. After 2 hours of stirring at room temperature, the reaction mixture was washed with saturated aqueous $\mathrm{Na}_{2} \mathrm{CO}_{3}$ solution $(3 \times$ $50 \mathrm{~mL}$ ), dried over $\mathrm{Na}_{2} \mathrm{SO}_{4}$, and concentrated on a rotary evaporator. The brown, oily residue was purified by column chromatography on silica. The product fraction showing greenish fluorescence was dried to yield $0.32 \mathrm{~g}$ red-brown solid (40\% isolated yield). ${ }^{1} \mathrm{H}$ NMR (500 $\mathrm{MHz}_{\mathrm{CDCl}}$ ): $\delta: 7.44-$ $7.42(\mathrm{~d}, 2 \mathrm{H}), 7.27-7.39(\mathrm{~m}, 3 \mathrm{H}), 7.26$ (d, 2H), 6.01 (s, 2H), 2.57 (s, 6H), 1.48 (s, 6H). ${ }^{13} \mathrm{C}$ NMR $(126$ $\left.\mathrm{MHz}, \mathrm{CDCl}_{3}\right):$ : 155.6, 142.9, 140.8, 138.1, 134.3, 133.3, 131.9, 131.3, 130.5, 129.4, 128.8, 127.8, 121.3, 14.6, 14.5. HRMS (ESI): Calculated for $\mathrm{C}_{25} \mathrm{H}_{23} \mathrm{BF}_{2} \mathrm{~N}_{2} \mathrm{SH}^{+}$433.1715; Found 433.1691.

c) Synthesis of PAG-1: compound 2 (50 mg, $0.7 \mathrm{mmol})$ was dissolved in of chlorobenzene $(2 \mathrm{~mL})$ in a $10 \mathrm{~mL}$ glass reaction vessel, diphenyliodonium hexafluoro phosphate $(50 \mathrm{mg}, 0.7 \mathrm{mmol}$ ) and copper (II) benzoate $0.005 \mathrm{~g}$ (5\% molar) were mixed in the dark while purged with nitrogen for 10 min. the microwave was adjusted to closed vessel standard mode; maximum temperature $170{ }^{\circ} \mathrm{C}$, maximum pressure $40 \mathrm{psi}$; maximum power $100 \mathrm{~W}$, high seeped stirring. The run time (the time at which the reaction approaches max temperature or pressure) was set for $1 \mathrm{~min}$. and the hold time 5 min. TLC was used to monitor the reaction. Upon the completion the solvent was evaporated to produce a dark red crude product. The resulting crude was purified by column chromatography using DCM/Methanol 9:1 to afford a red solid crystal of $45 \mathrm{mg}$ (60\% isolated yield). ${ }^{1} \mathrm{H}$ NMR (500 MHz, $\left.\mathrm{CDCl}_{3}\right)$ 8: $7.80(\mathrm{~d}, 2 \mathrm{H}), 7.79-7.66(\mathrm{~m}, 4 \mathrm{H}), 7.64(\mathrm{~d}, 2 \mathrm{H}), 6.01(\mathrm{~s}, 2 \mathrm{H}), 2.57(\mathrm{~s}, 6 \mathrm{H}), 1.48(\mathrm{~s}, 6 \mathrm{H}) .{ }^{13} \mathrm{C}$ NMR (126 MHz, $\left.\mathrm{CDCl}_{3}\right)$ 8: 156.7, 142.4, 142.0, 137.2, 135.2, 132.0, 131.7, 131.4, 131.2, 130.6, 125.6, 125.6, 123.5, 122.0, 14.6, 14.5. HRMS (ESI) m/z: $[\mathrm{M}+\mathrm{H}]{ }^{+}$Calculated for $\mathrm{C}_{31} \mathrm{H}_{28} \mathrm{BF}_{2} \mathrm{~N}_{2} \mathrm{~S}^{+}$509.4397; Found 509.2073.

d) Synthesis of compound (3) [2]: Trifluoroacetic acid (30 $\mu \mathrm{L}, 0.40 \mathrm{mmol})$ in dry $\mathrm{CH}_{2} \mathrm{Cl}_{2}(15 \mathrm{~mL})$ was added drop wise to a solution of 3,4,5-trimethoxybenzaldehyde $(1 \mathrm{~g}, 5.1 \mathrm{mmol})$ and 2,4-dimethyl-1Hpyrrole $(1 \mathrm{~mL}, 9.7 \mathrm{mmol})$ in dry $\mathrm{CH}_{2} \mathrm{Cl}_{2}(15 \mathrm{ml})$ at room temperature. The reaction mixture was stirred 
for 12 hours at room temperature, 2, 3-Dichloro-5, 6-dicyano-1, 4-benzoquinone (2.16 g, $9.7 \mathrm{mmol})$ was added under ice bath cooling and the mixture was stirred for $30 \mathrm{~min}$. After stirring for 1 hour at room temperature, diisopropyl ethylamine (DIPEA) $(30 \mathrm{~mL}, 243 \mathrm{mmol})$ was added, followed by slow addition of $\mathrm{BF}_{3}-\mathrm{Et}_{2} \mathrm{O}(30 \mathrm{~mL}, 243 \mathrm{mmol})$. After 3 hours of stirring at room temperature, the reaction mixture was washed with saturated aqueous $\mathrm{NaHCO}_{3}$ solution $(3 \times 50 \mathrm{~mL})$, dried over $\mathrm{Na}_{2} \mathrm{SO}_{4}$, and concentrated by reduced pressure. The brown, oily residue was purified by silica gel column chromatography (ethyl acetate: hexane $=1: 9 \mathrm{v} / \mathrm{v})$ to obtain $0.76 \mathrm{~g}$ dark green crystal $(37 \%$ isolated yield). ${ }^{1} \mathrm{H}$ NMR (500 MHz, $\mathrm{CDCl}_{3}$ ): $\delta: 6.46$ (s, 2H), 5.93 (s, 2H), 3.85 (s, 3H), 3.76 (s, 6H), 2.49 (s, 6H), 1.46 (s, 6H). ${ }^{13} \mathrm{C}$ NMR (126 MHz, $\left.\mathrm{CDCl}_{3}\right):$ : 155.6, 154.2, 143.0, 141.3, 138.6, 131.3, 130.1, 121.2, 105.1, 61.3, 56.3, 30.9, 14.2.

e) Synthesis of 4-(phenylthio)styryl-BODIPY (4): compound 3 (50 mg, $0.12 \mathrm{mmol}$ ) was dissolved in $3 \mathrm{~mL}$ dimethylformamide (DMF) in a $10 \mathrm{~mL}$ glass reaction vessel, followed by 4(phenylthio)benzaldehyde $(43 \mathrm{mg}, 0.18 \mathrm{mmol})$, acetic acid $(0.25 \mathrm{~mL})$ and piperidine $(0.25 \mathrm{~mL})$ were added. The microwave was adjusted to closed vessel standard mode; maximum temperature $150^{\circ} \mathrm{C}$, maximum pressure 40 psi; maximum power $100 \mathrm{~W}$, high speed stirring. The run time (the time at which the reaction approaches max temperature or pressure) was set for $5 \mathrm{~min}$. And the hold time is 15 min. TLC was used to monitor the reaction. The reaction mixture was washed with saturated aqueous $\mathrm{NaCl}$ solution $(3 \times 20 \mathrm{~mL})$, dried over $\mathrm{Na}_{2} \mathrm{SO}_{4}$, and concentrated by reduce pressure. The crude product was purified by silica gel column chromatography (ethyl acetate: hexane $=1: 9 \mathrm{v} / \mathrm{v}$ ) and afforded with a purple solid (25 mg, 30\% isolated yield). ${ }^{1} \mathrm{H} \mathrm{NMR}\left(500 \mathrm{MHz}, \mathrm{CDCl}_{3}\right): 8: 7.64(\mathrm{~d}, 1 \mathrm{H})$, $7.50(\mathrm{~d}, 2 \mathrm{H}), 7.40(\mathrm{~d}, 2 \mathrm{H}), 7.34(\mathrm{t}, 2 \mathrm{H}), 7.31-7.27(\mathrm{~m}, 2 \mathrm{H}), 7.18(\mathrm{~d}, 2 \mathrm{H}, \mathrm{J}=16 \mathrm{~Hz}), 6.6(\mathrm{~s}, 1 \mathrm{H}), 6.55$ (s, 2H), 6.04 (s, 1H), 3.93 (s, 3H), 3.84 (s, 6H), 2.59 (s, 3H), 1.57 (d, 6H). ${ }^{13} \mathrm{C}$ NMR (126 MHz, $\left.\mathrm{CDCl}_{3}\right)$ : $: 155.9,154.2,152.4,143.0,142.2,140.1,138.7,137.4,135.0,134.8,131.9,131.8,130.3,130.1,129.3$, 128.0, 127.5, 121.4, 119.2, 117.5, 105.3, 61.3, 56.4, 29.7, 14.7, 14.4, 14.3, 14.1. HRMS(ESI) $\mathrm{m} / \mathrm{z}:[\mathrm{M}+\mathrm{H}]+$ Calculated for $\mathrm{C}_{35} \mathrm{H}_{33} \mathrm{BF}_{2} \mathrm{~N}_{2} \mathrm{O}_{3} \mathrm{~S}$ 610.2267, Found 610.2259.

f) Synthesis of PAG-2: compound $4(50 \mathrm{mg}, 0.082 \mathrm{mmol})$ was dissolved in chlorobenzene $(2 \mathrm{~mL})$ in a $10 \mathrm{~mL}$ glass reaction vessel, diphenyliodonium hexafluoro phosphate $(100 \mathrm{mg}, 0.235 \mathrm{mmol})$ and copper (II) benzoate $0.05 \mathrm{~g}$ ( $5 \%$ molar ratio) were mixed in the dark while purged with nitrogen for $10 \mathrm{~min}$. The microwave was adjusted to closed vessel standard mode; maximum temperature $170^{\circ} \mathrm{C}$, maximum pressure $40 \mathrm{psi}$; maximum power $100 \mathrm{~W}$, high speed stirring. The run time (the time at 
which the reaction approaches max temperature or pressure) was set for $5 \mathrm{~min}$. TLC was used to monitor the reaction. Upon the completion the solvent was removed by reduced pressure to get a dark red crude product. The crude product was purified by silica gel column chromatography (methanol: dichloromethane $=3: 97 \mathrm{v} / \mathrm{v}$ ) to afford a deep red solid (10 mg, 15\% isolated yield). The purity of the resulting PAG-2 was tested using LCMS-TOF (Agilent Technologies, HPLC model \#1200HPLC, TOF-MS model \#G1969A), in which C18 column (4.6 $\times 50 \mathrm{~mm}, 2.7 \mu \mathrm{m})$ was used and the eluent was a mixture of acetonitrile and water (gradient eluent 0 to $100 \%$, flow rate of $1 \mathrm{~mL} / \mathrm{min}$ ). ${ }^{1} \mathrm{H}$ NMR (500 MHz, $\mathrm{CDCl}_{3}$ ) 8: 7.85 (d, 2H), 7.84-7.73 (m, 12H), 7.20 (d, 2H, J=15), 6.67 (s, 1H), 6.54 (s, 2H), 6.09 (s, 1H), 3.93 (s, 3H), 3.85 (s, 6H), 2.59 (s, 3H), 1.59 (d, 6H). ${ }^{13} \mathrm{C} \mathrm{NMR}\left(151 \mathrm{MHz}, \mathrm{CDCl}_{3}\right)$ : 8: 158.9, 154.7, 149.8, 143.8, 142.0, 141.5, 139.3, 134.9, 132.0, 131.4, 130.0, 125.1, 124.7, 122.9, 122.4, 118.2, 111.3, 105.5, 61.7, 56.8, 56.3, 30.1, 15.3, 14.8, 14.7, 14.5. HRMS (ESI) m/z: [M]+ Calculated for $\mathrm{C}_{41} \mathrm{H}_{38} \mathrm{BF}_{2} \mathrm{~N}_{2} \mathrm{O}_{3} \mathrm{~S}+$ 687.2658; Found 687.2639.

\section{Photophysical properties of PAG-1 and PAG-2}

a) Absorption, Emission spectra and fluorescent quantum yield of compound PAG-1 and PAG-2: All steady-state absorption, fluorescence emission, of compound PAG-1 and PAG-2 were investigated in $10 \mathrm{~mm}$ path length quartz cuvettes at room temperature. The absorption spectra were measured with a Tecan Infinite M200 PRO plate reader spectrometer in $1 \mathrm{~cm}$ path length quartz cuvettes. Fluorescence emission and excitation spectra were obtained using an Edinburgh Photonics FLS980 spectrometer equipped with a thermoelectric cooled photo multiplier detector (Hamamatsu) and a liquid-nitrogen cooled NIR-photomultiplier detector (Hamamatsu). All measurements were carried out with the optical density below 0.12 at the excitation wavelength to avoid reabsorption. The excitation and fluorescence emission spectra were corrected for the spectral sensitivity of Edinburgh Photonics excitation and detection system using factory-measured correction files.

b) Fluorescence quantum yields were determined by a reference point method. Fluorescein as standard / exe at $496 \mathrm{~nm}$ in $0.1 \mathrm{M} \mathrm{NaOH}\left(\phi_{\mathrm{f}}\right)=0.95$ was used as a standard sample to calculate the fluorescence quantum yield of PAG-1, and crystal violet perchlorate as standard/ exe at $540 \mathrm{~nm}$ in $\mathrm{MeOH}\left(\phi_{\mathrm{f}}\right)=0.54$ was used as a standard to calculate the fluorescence quantum yield of PAG-2. The equation as follow. 


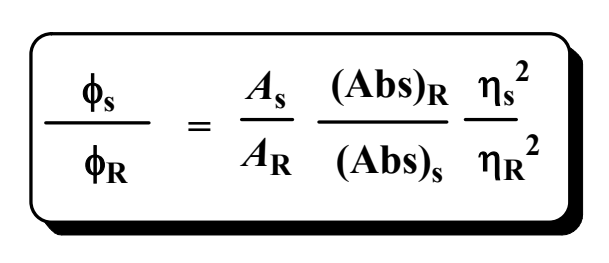

Where $\Phi$ represents quantum yield, Abs represents absorbance, $\boldsymbol{A}$ represents area under the fluorescence curve, and $\eta$ is refractive index of the medium. The subscripts $\mathrm{S}$ and $\mathrm{R}$ denote the corresponding parameters for the sample and reference, respectively.

c) Fluorescence lifetimes $\left(\tau_{\mathrm{F}}\right)$ were determined with the single photon counting technique (TCSPC) and the same fluorescence spectrometer using a pulsed picosecond diode laser (EPL-505) as the excitation source. Molar absorption coefficients $(\varepsilon)$ and maximum absorbance wavelengths $\left(\lambda_{\max }\right)$ were determine in acetonitrile using Beer's law, from plots of absorbance vs. concentration. Recordings were performed in $10 \mathrm{~mm}$ path length quartz cuvettes at room temperature.
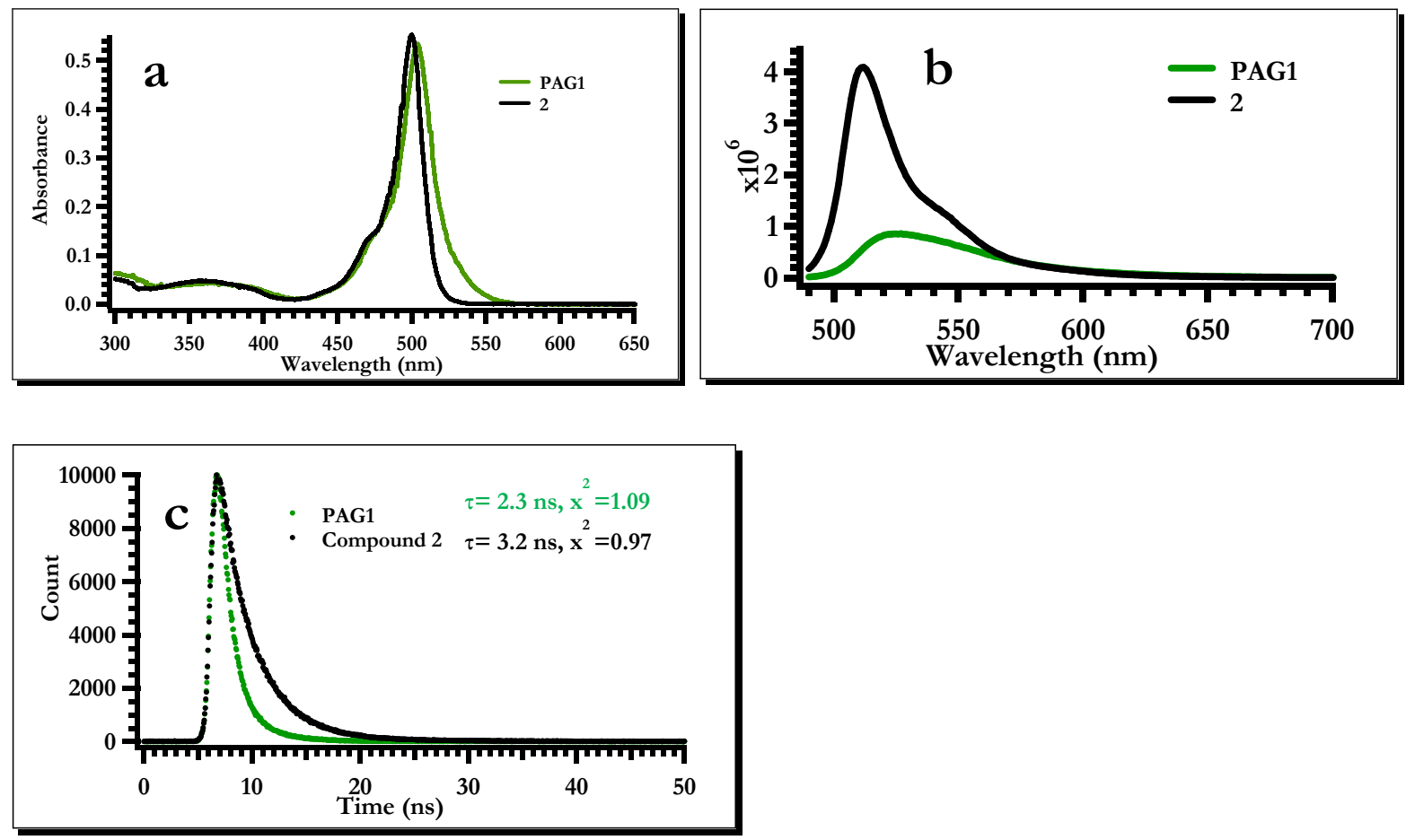

Figure S1: a) UV-vis absorption spectra b) emission spectra C) life time of PAG-1 and precursor compound 2 in methanol. 

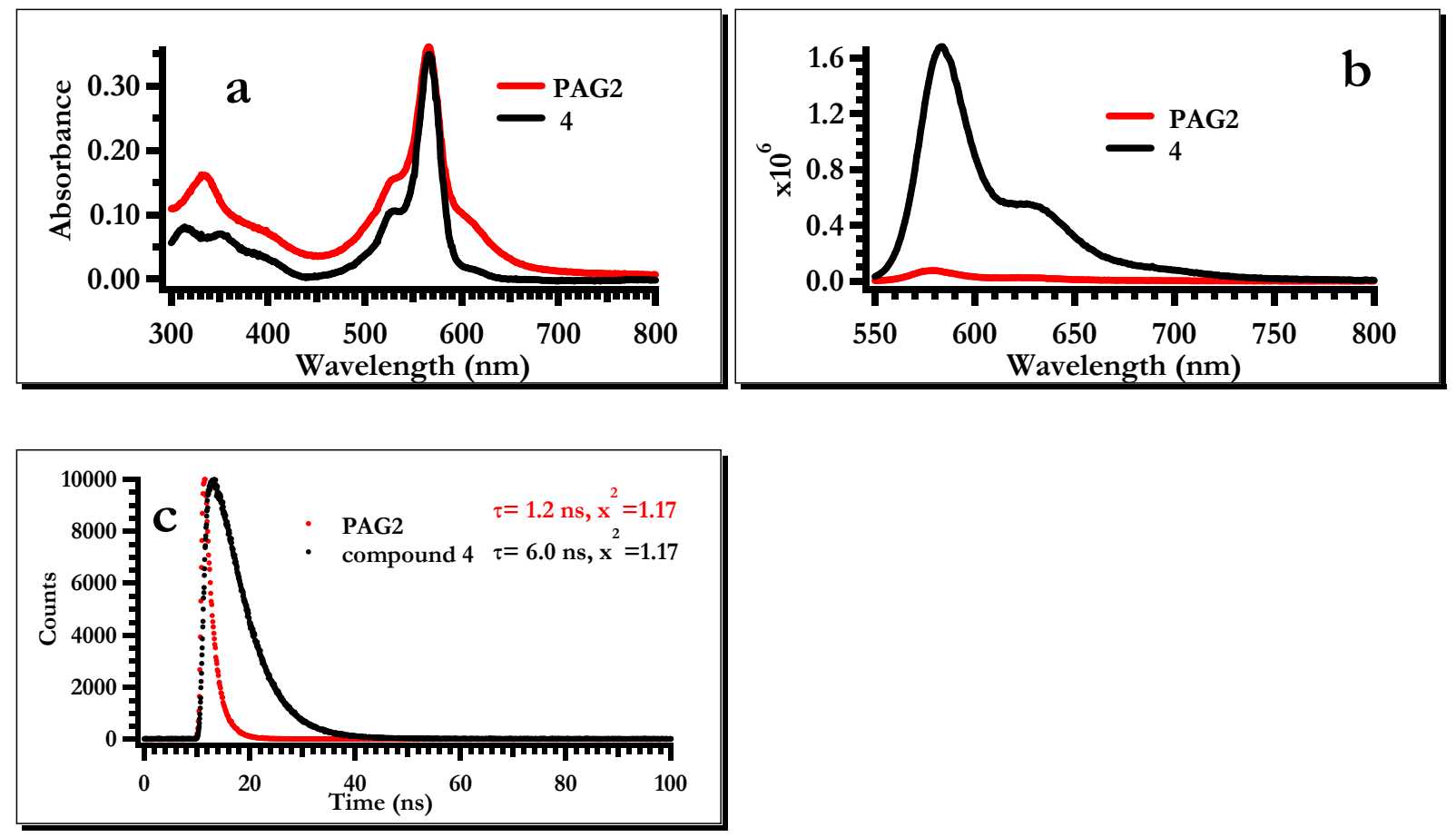

Figure S2: a) UV-vis absorption spectra, b) emission spectra, C) life time of PAG-2 and precursor compound 4 in methanol.

Table S1: Photophysical Properties (fluorescence quantum yield $\Phi_{\mathrm{f}}$ and fluorescence life-time $\tau_{\mathrm{f}}$ ) of compounds 2 and 4 when compared with PAG-1 and PAG-2.

\begin{tabular}{|l|l|l|}
\hline Compound & $\Phi_{\mathrm{f}}$ & $\tau_{\mathrm{f}}(\mathrm{ns})$ \\
\hline 2 & 0.30 & 3.2 \\
\hline PAG1 & 0.11 & 2.3 \\
\hline 4 & 0.45 & 6.0 \\
\hline PAG2 & 0.02 & 1.2 \\
\hline
\end{tabular}

3. Dark stability: PAG-1 and PAG-2 $\left(2 \mathrm{~mL}\right.$ of $1 \times 10^{-5} \mathrm{M}$ in $\left.\mathrm{MeOH} / \mathrm{Water}(1 / 1 \mathrm{v} / \mathrm{v})\right)$ was placed in quartz cuvette $(10 \mathrm{~mm}$ path). The cuvette was placed in the dark condition at room temperature. After $24 \mathrm{~h}$ the cuvette was analysis by UV-Vis absorbance spectra. There is no change in absorbance spectra. 

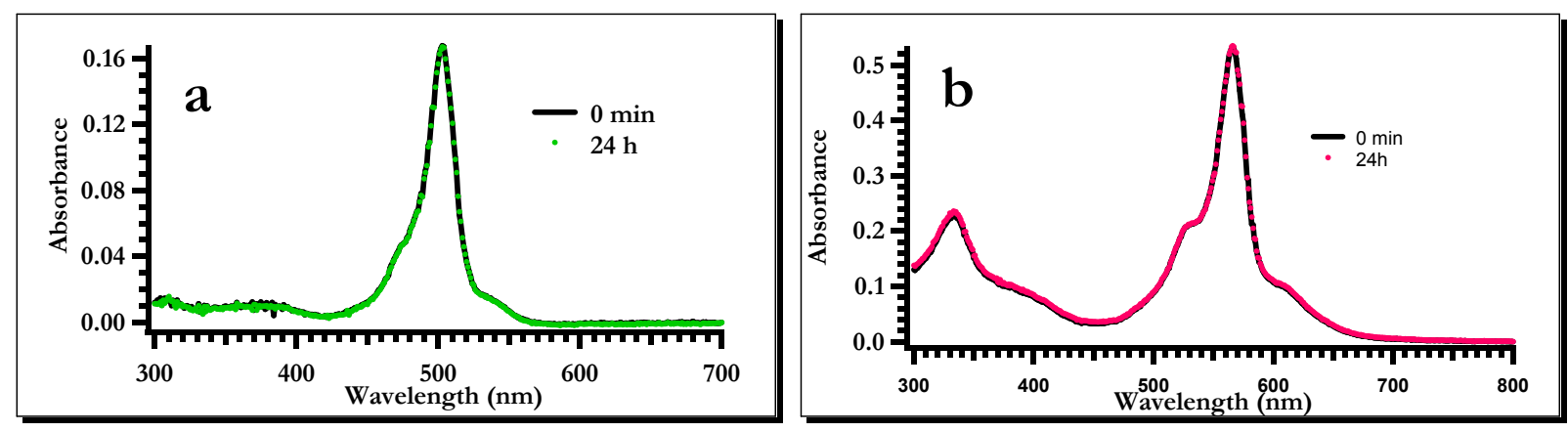

Figure S3: a) UV-vis absorption spectra of PAG-1 at 0 min and $24 \mathrm{~h}$ in methanol in the dark, b) UVvis absorption spectra of PAG-2 at $0 \mathrm{~min}$ and $24 \mathrm{~h}$ in methanol in the dark condition (all measurements were conducted at room temperature).

4. Photochemical properties and stabilities of PAGs.

a) Photolysis of PAG-1 and PAG-2: PAG-1 (2 mL of $1 \times 10^{-5} \mathrm{M}$ in $\mathrm{MeOH} /$ Water $\left.(1 / 1 \mathrm{v} / \mathrm{v})\right)$ was placed in quartz cuvette $(10 \mathrm{~mm}$ path). The cuvette was placed in front of a light source (Thorlab's M505L3) mounted LED has a nominal wavelength $503 \mathrm{~nm}$ with a power density of $80 \mathrm{~mW} / \mathrm{cm}^{2}, 1$ $\mathrm{cm}$ distance and irradiated for the indicated times. At regular interval of time point, the cuvette was analysis by UV-Vis spectrophotometer, emission spectra. The same protocol was repeated for PAG2 with light source (Thorlab's M595) mounted LED has a nominal wavelength $595 \mathrm{~nm}$ with a power density of $80 \mathrm{~mW} / \mathrm{cm}^{2}, 1 \mathrm{~cm}$ distance and irradiated for the indicated times.
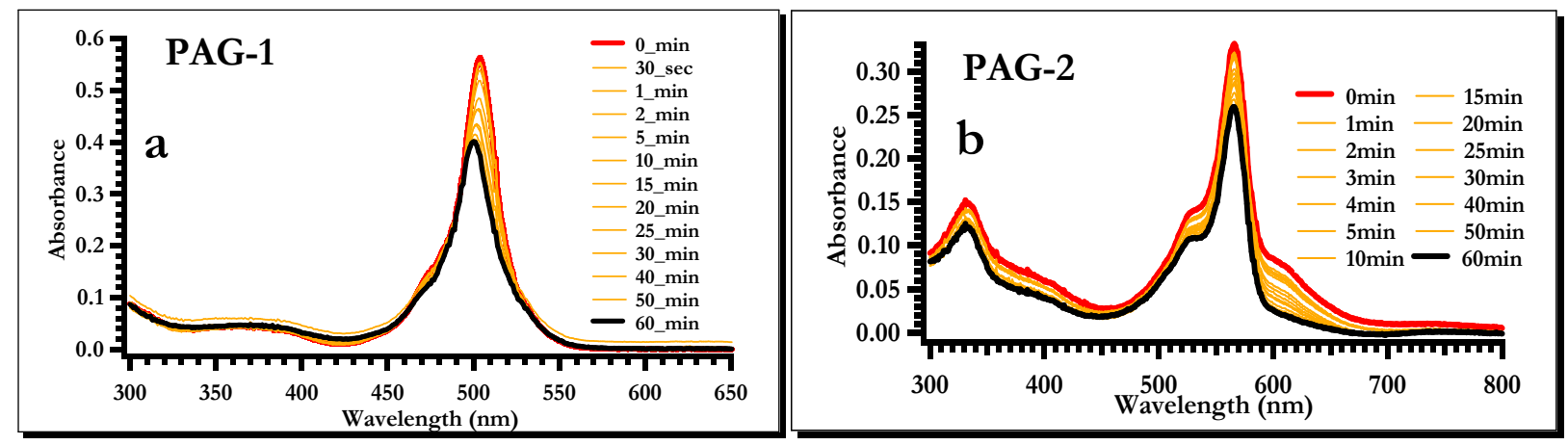

Figure S4. UV-Vis absorption changes of PAG-1 (a) and PAG-2 (b) (c $\left.\approx 1 \times 10^{-5} \mathrm{M}\right)$ during photolysis in methanol/water (1/1 v/v). PAG-1 and PAG-2 were irradiated using green and red LED, separately.

b) Thermal stability of PAG-2: PAG-2 $\left(1 \times 10^{-5} \mathrm{M}\right.$ in methanol $)$ in a corvette was merged in a water bath with controlled temperatures, 20, 40, $60{ }^{\circ} \mathrm{C}$, separately. After the PAG-2 solution was steady at 
the set temperature for $30 \mathrm{~min}$, the solution was slowly cooled down to room temperature for the UV-Vis measurement. Comparing the absorbance, it showed ignorable changes in varied temperatures.

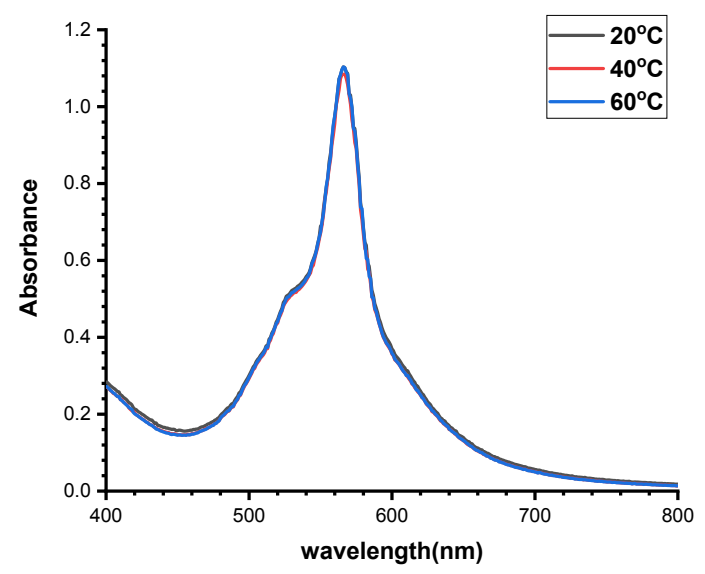

Figure S5: UV-vis absorption spectra of PAG-2 $\left(1 \times 10^{-5} \mathrm{M}\right.$ in methanol $)$ after kept at $20,40,60{ }^{\circ} \mathrm{C}$ for $30 \mathrm{~min}$. Spectra were recorded after slowly cool down the solution to room temperature.

c) $\mathrm{pH}$ stability of PAG-2. A stock solution of PAG-2 in DMSO was added to varied pH buffer solutions made of sodium acetate and acetic acid (0.4 M). The final concentration of PAG-2 was $1 \times 10^{-5}$ M. UV-Vis spectra were recorded right after the PAG-2 buffer solutions were made (black curves), and 24 hrs after the PAG-2 buffer solution were stored in the dark condition. Meanwhile, three buffer solution condition were tested, $\mathrm{pH} \sim 2.8,3,8$ and 4.9. In all conditions, the absorbance of PAG-2 solution exhibit ignorable changes and showed stability in the acidic conditions.
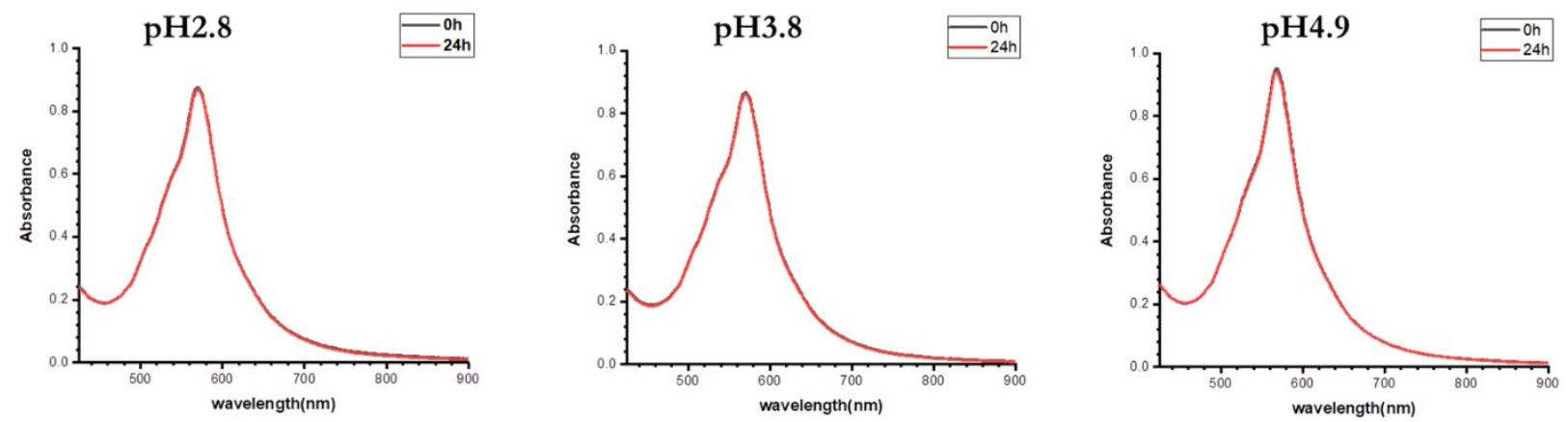

Figure S6: UV-vis absorption spectra of PAG-2 in varied pH buffer solutions (sodium acetate/acetic acid, $\mathrm{pH}$ of 2.8, 3.8 and 4.9). Spectra were measured right after the solutions were prepared (black curve, $0 \mathrm{~h}$ ), and after $24 \mathrm{hrs}$ in dark condition (red curve, $24 \mathrm{~h}$ ). 
d) qualitative analysis of PAG-1 by LC-MS: 2 mL of PAG-1 $\left(1 \times 10^{-5} \mathrm{M}\right)$ in MeOH/Water $\left.(7 / 3 \mathrm{v} / \mathrm{v})\right)$ solution was placed in quartz cuvette $(10 \mathrm{~mm}$ path). They were irradiated under mounted LED has a wavelength of $503 \mathrm{~nm}$ with the output power of $80 \mathrm{~mW} / \mathrm{cm}^{2}$. At regular interval of time, $50 \mu \mathrm{L}$ of the aliquots was taken and analyzed by LC-MS using mobile phase acetonitrile/water $(95 / 5 \mathrm{v} / \mathrm{v})$, at a flow rate of $0.1 \mathrm{~mL} / \mathrm{min}$ (detection: UV-Vis at $500 \mathrm{~nm}$ ). The reaction was followed until the consumption of the starting material. The peaks were analyzed by injecting authentic samples.

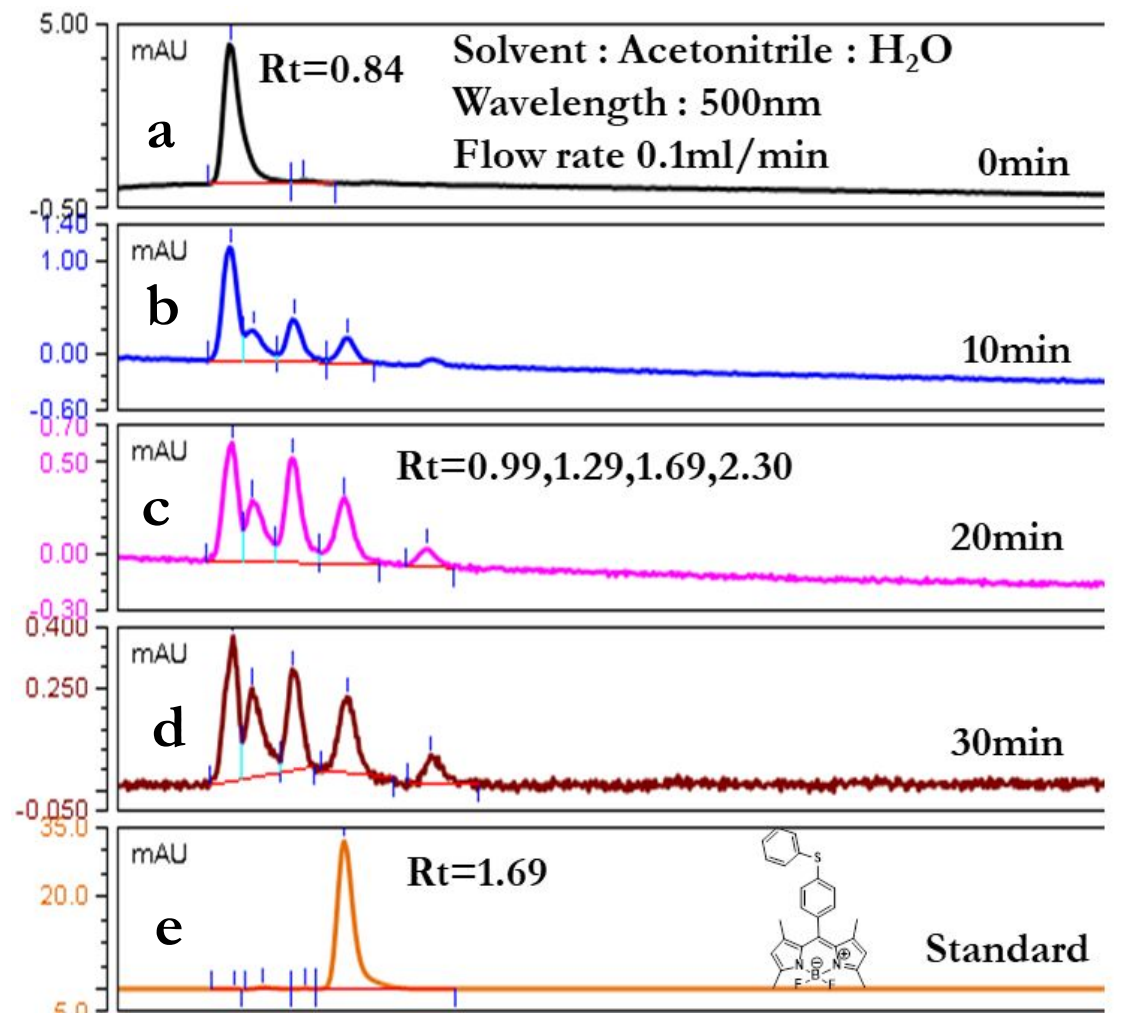

Figure S7: LC-MS profile of PAG-1 at regular time intervals upon green LED irradiation. a) 0, b) 10, c) 20 , d) 30 min e) authentic sample of compound 2. Detected by UV absorption at $500 \mathrm{~nm}$. 


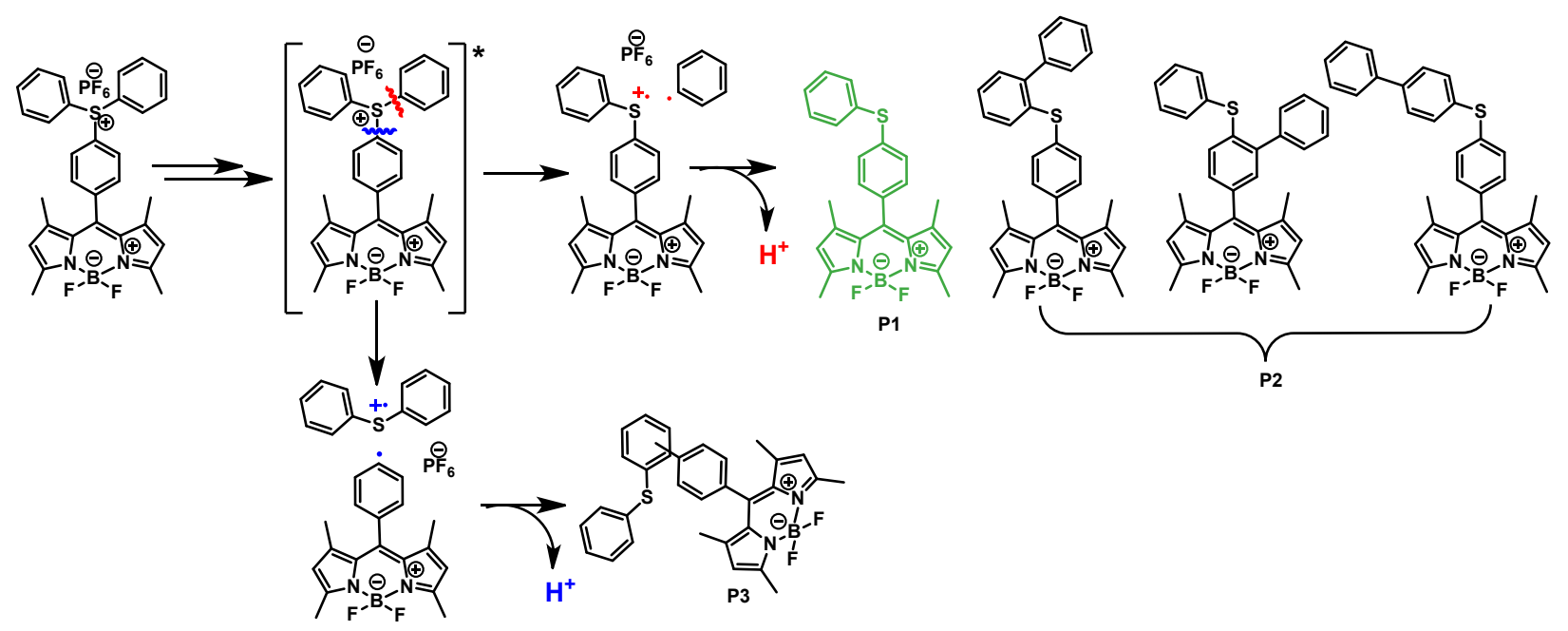

Scheme S2: Proposed photolysis mechanism of PAG-1.

5. Estimation of $\mathrm{H}^{+}$generation ability and quantum yield was calculating using $\mathrm{pH}$ sensitive dye HPTS (Thermo Fisher) indicator: Our situation is further complicated due to the presence of absorbing molecule (e.g., PAG-1 and PAG-2) with overlapping absorption spectra with the pH probe. Thus, to provide an estimate of $\mathrm{pH}$ change, we used an approach previously found to quantify the concentration of photoacid molecules generated/photons absorbed by PAG-1 has consisted using $\mathrm{pH}$ indicator. HPTS dye undergoes a pH-dependent absorbance shift from $455 \mathrm{~nm}$ to $405 \mathrm{~nm}$. PAG1/PAG-2 $\left(4.0 \times 10^{-4} \mathrm{M}\right.$ and $\left.4.6 \times 10^{-4} \mathrm{M}\right)$ and $0.1 \mathrm{mM}$ of HPTS in Locke's solution was irradiated at the mounted LED with desired wavelength of $505 \mathrm{~nm}$ and $595 \mathrm{~nm}$ with beam irradiance: $80 \mathrm{~mW}$ $/ \mathrm{cm}^{2}$ for up to $60 \mathrm{~min}$ of irradiation to generate the calibration curve. Proton generation was estimated to be $2.36 \times 10^{-8}$ and $1.66 \times 10^{-8} \mathrm{M} \mathrm{L}^{-1} \mathrm{~s}^{-1}$. The cuvette was placed in front of a light source mounted LED with a power density of $80 \mathrm{~mW} / \mathrm{cm}^{2}$. The power density was measured by PM100D Compact Power and Energy Meter (Thorlabs) and the value was confirmed by using photometer IL1400A (International Light). The LED light spectra were obtained from the vendor, and a wavelength-power density diagram were plotted. After integrating the plots, the total numbers of photons (light flux) were calculated by sum up the ones at different wavelengths. The quantum yields of acid generation $\left(\Phi_{\mathrm{H}+}\right)$ of PAG-1 and PAG-2 were determined to be 0.07 and 0.04 respectively. 


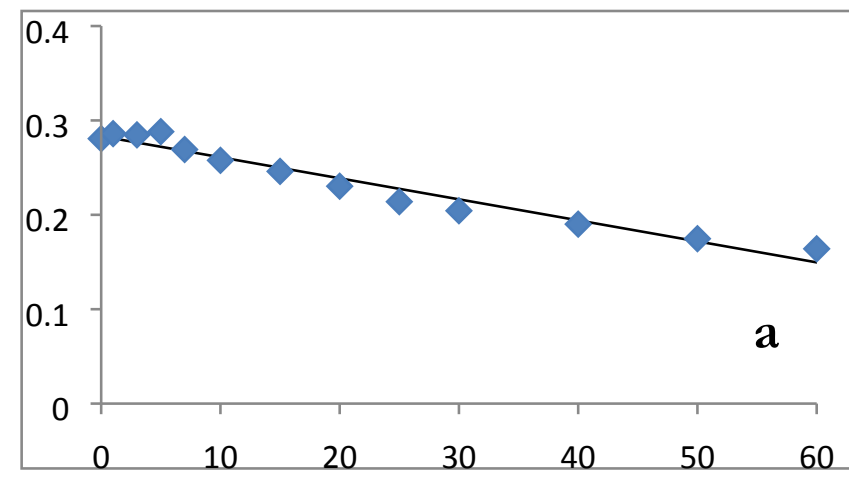

Exposure Time (min)

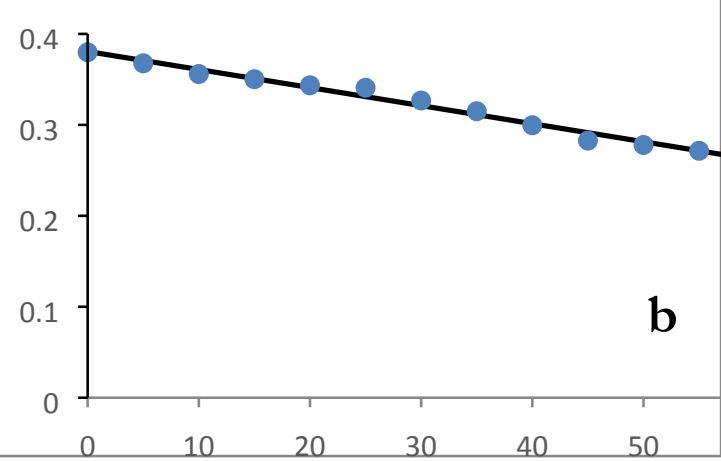

Exposure Time (min)

Figure S8: A solution of PAG-1 and PAG-2 and 0.1 mM of HPTS was exposed to green and red LED ( $80 \mathrm{~mW} / \mathrm{cm}^{2}$ ) separately, for $60 \mathrm{~min}$ to prepare a dose dependent calibration curve. a) green LED irradiation time depend absorption change of HPTS with PAG-1 at wavelength of $(505 \pm 30 \mathrm{~nm}$, $80 \mathrm{~mW} / \mathrm{cm}^{2}$ ), and b) irradiation time depend absorption change of HPTS with PAG-2 at wavelength of $\left(595 \pm 30 \mathrm{~nm}, 80 \mathrm{~mW} / \mathrm{cm}^{2}\right)$.

6. Photo initiated Cationic Polymerization of Cyclohexene oxide: Photoinduced cationic polymerization was carried out for cyclohexene oxide as a monomer. The sample tube was charged with cyclohexene oxide (50 mg) and PAG-2 (0.4 mg, $0.12 \mathrm{~mol} \%)$, sealed with rubber septum, and purged with nitrogen for 5 min prior to irradiation. After the sample was irradiated for 30 min with $\operatorname{LED}\left(595 \pm 30 \mathrm{~nm}, 80 \mathrm{~mW} / \mathrm{cm}^{2}\right)$, the reaction mixture was diluted and measured with MS. In addition, the mixture after 30 min light irradiation was subject to ${ }^{1} \mathrm{H}$ NMR analysis, and the peaks belong to cyclohexene oxide monomer (peak b) and oligomer (peak a) were used to calculate the conversion yield of the photo-induced polymerization. Furthermore, GC (Thermo Scientific TRACE1300 with flame ionization detector, front inlet gas: helium, oven temperature $200{ }^{\circ} \mathrm{C}$ ) was used to monitor the cyclohexene monomer in the course, and an irradiation time dependent kinetic curve is plotted.
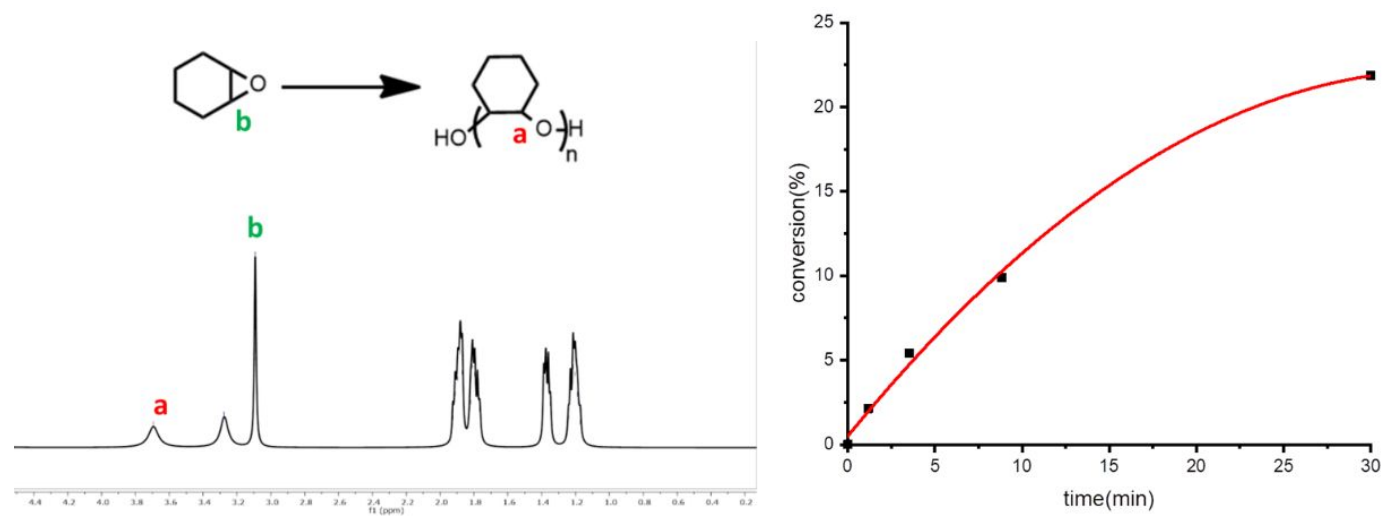
Figure S9. The ${ }^{1} \mathrm{H}$ NMR spectrum of the mixture (with PAG-2, same component as in Figure 4) after 30 min LED irradiation induced polymerization, the peaks for cyclohexene monomer and oligomer are assigned (left). The photo-induced polymerization kinetic curve plotted (right).

\section{References:}

[1] Christophe Hardouin, Michael J. Kelso, F. Anthony Romero, Thomas J. Rayl, Donmienne Leung, Inkyu Hwang, Benjamin F. Cravatt, Dale L. Boger. Journal of Medicinal Chemistry, 2007, 50(14), 33593368.

[2] Ge Meng, Singaravelu Velayudham, Adrian Smith, Rudy Luck, Haiying Liu. Macromolecules 2009, 42(6), 1995-2001. 
${ }^{1} \mathrm{H},{ }^{13} \mathrm{C}$ and MS spectra:
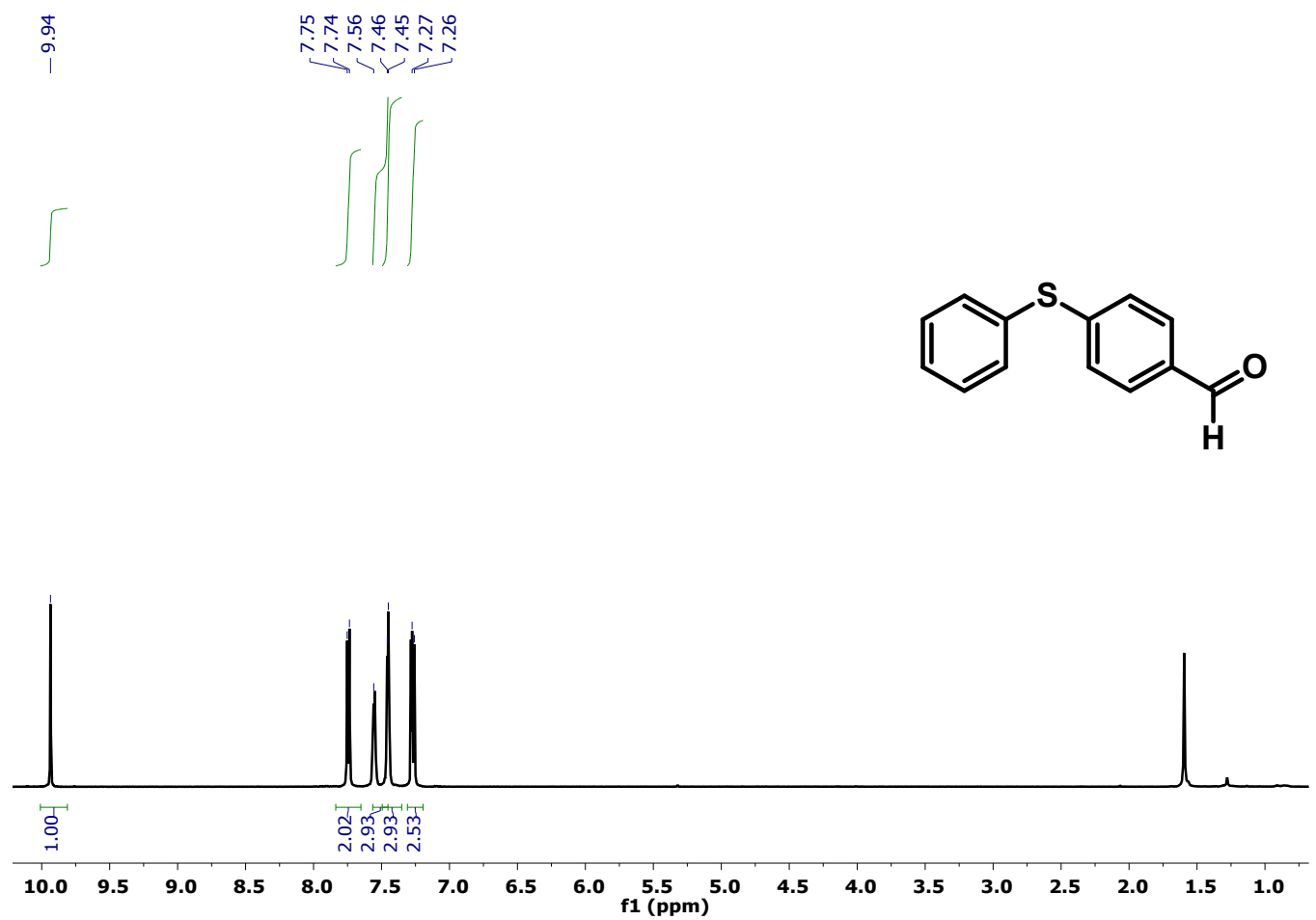

${ }^{1} \mathrm{H}$ NMR of 4-(phenylthio)benzaldehyde (1)
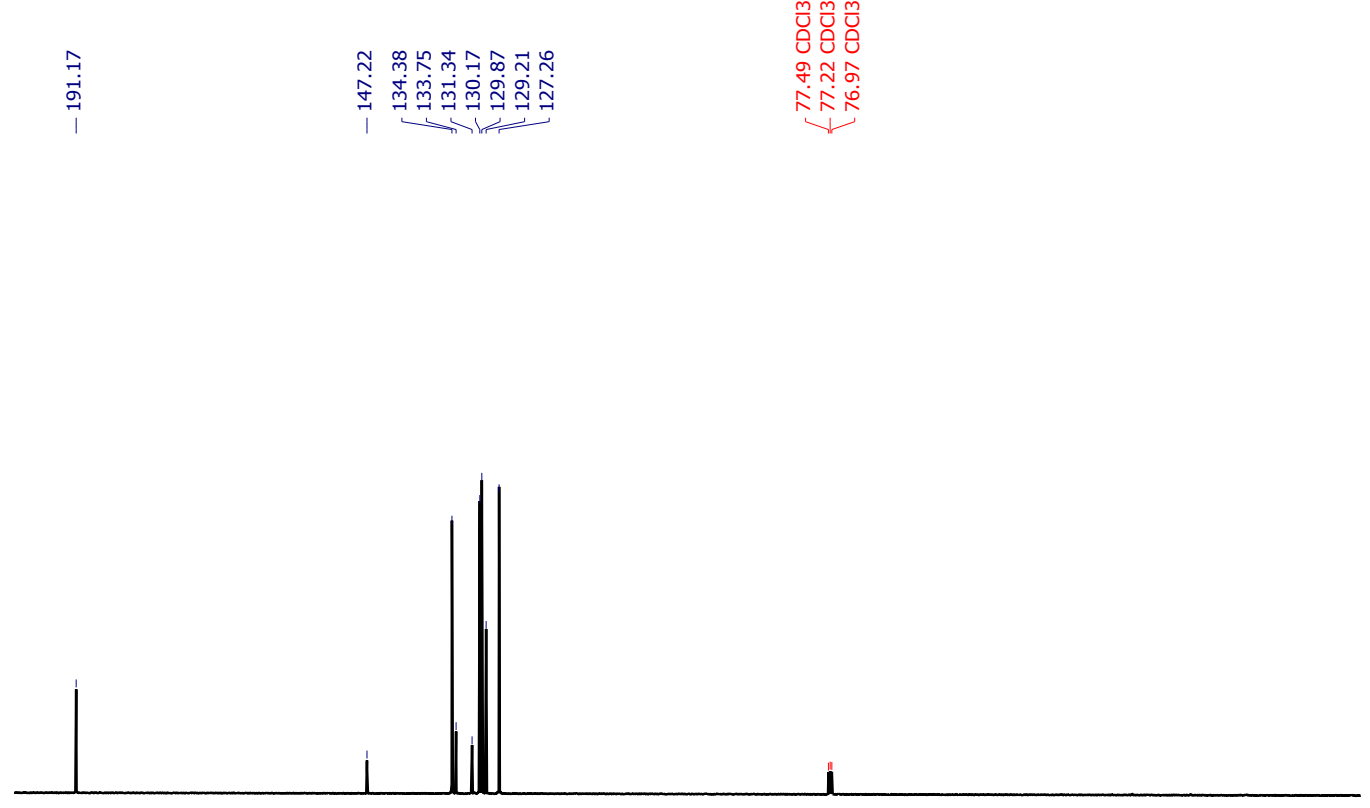

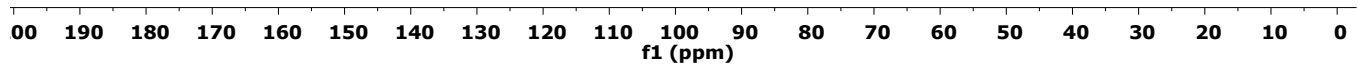

${ }^{13} \mathrm{C}$ NMR of 4-(phenylthio)benzaldehyde (1) 


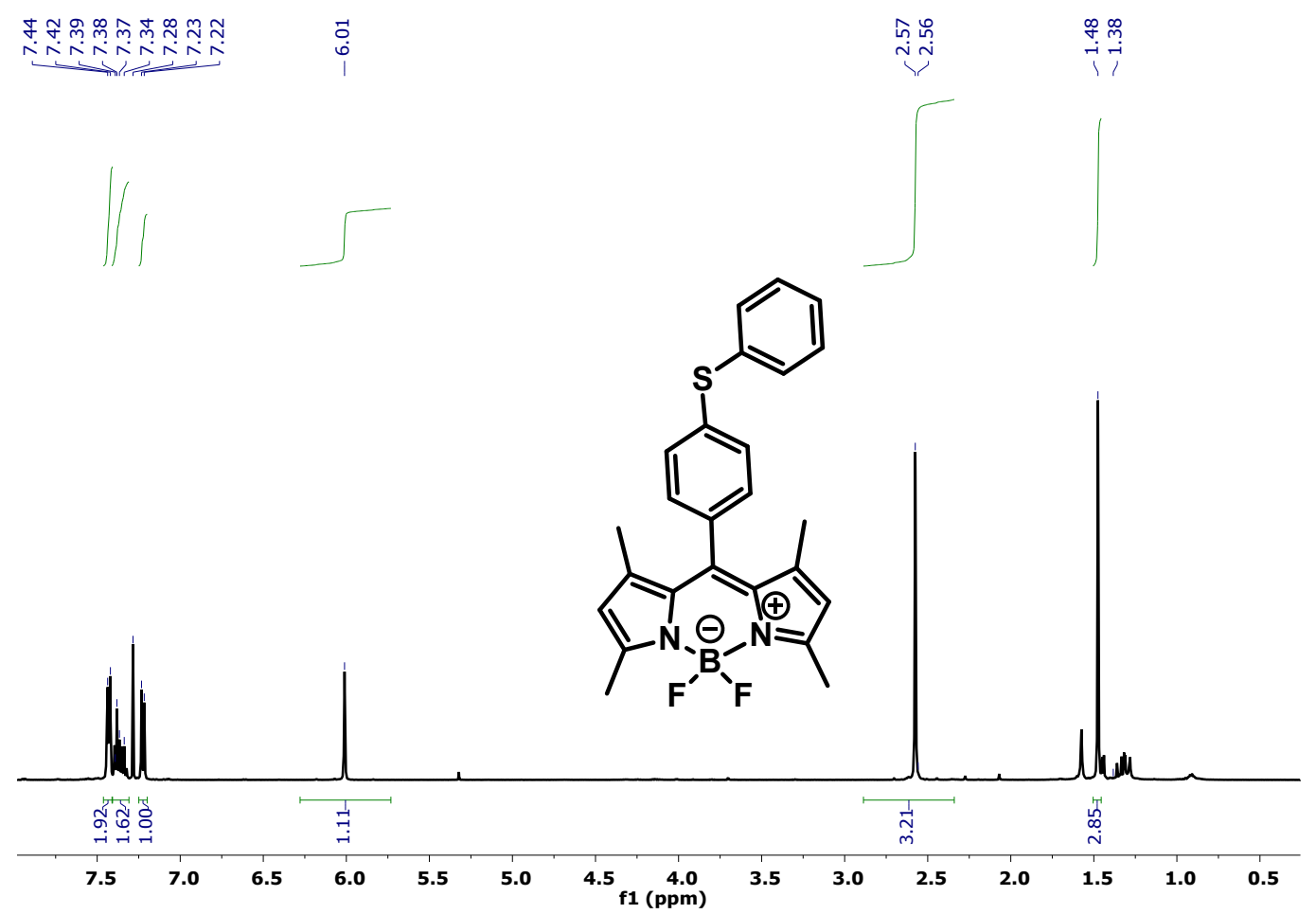

${ }^{1} \mathrm{H}$ NMR of 4-(phenylthio)BODIPY (2)

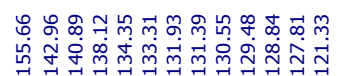

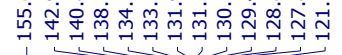

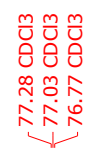

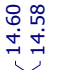

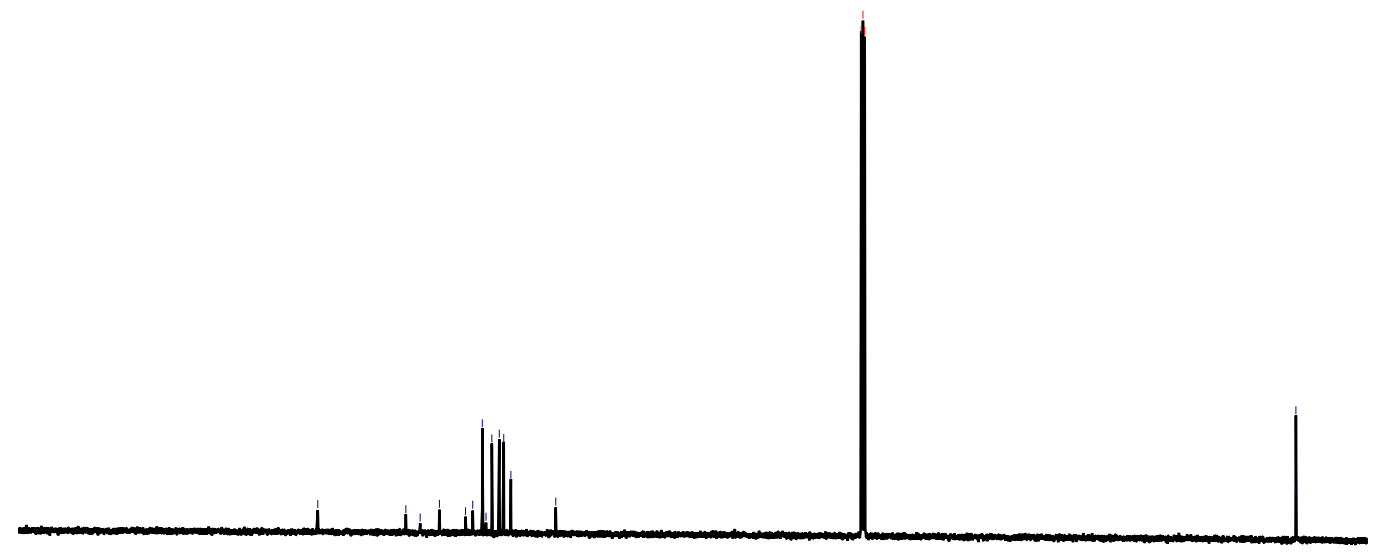

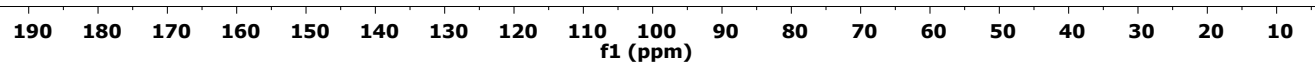

${ }^{13} \mathrm{C}$ NMR of 4-(phenylthio)BODIPY (2) 


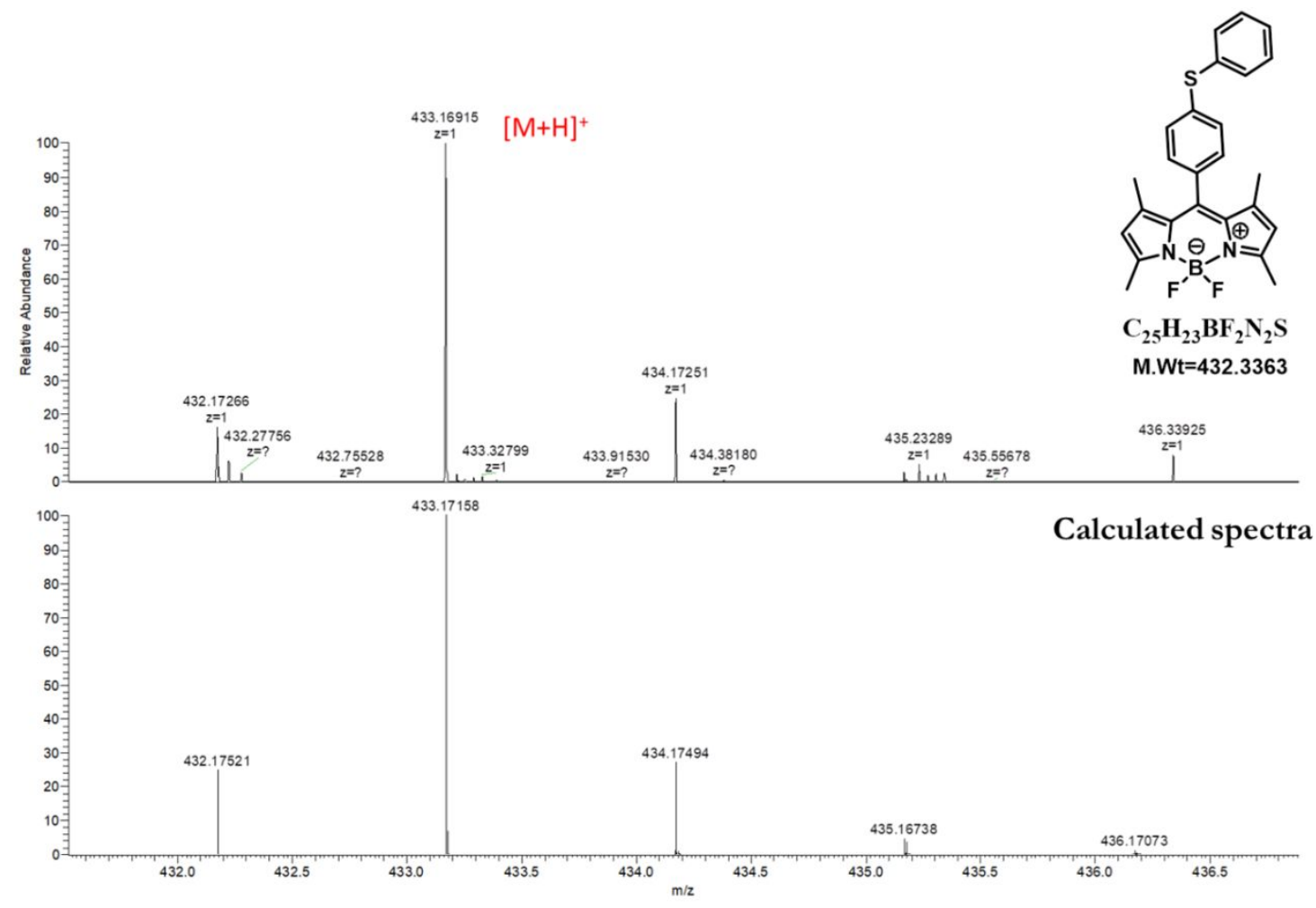

Mass spectrum of 4-(phenylthio)BODIPY (2)

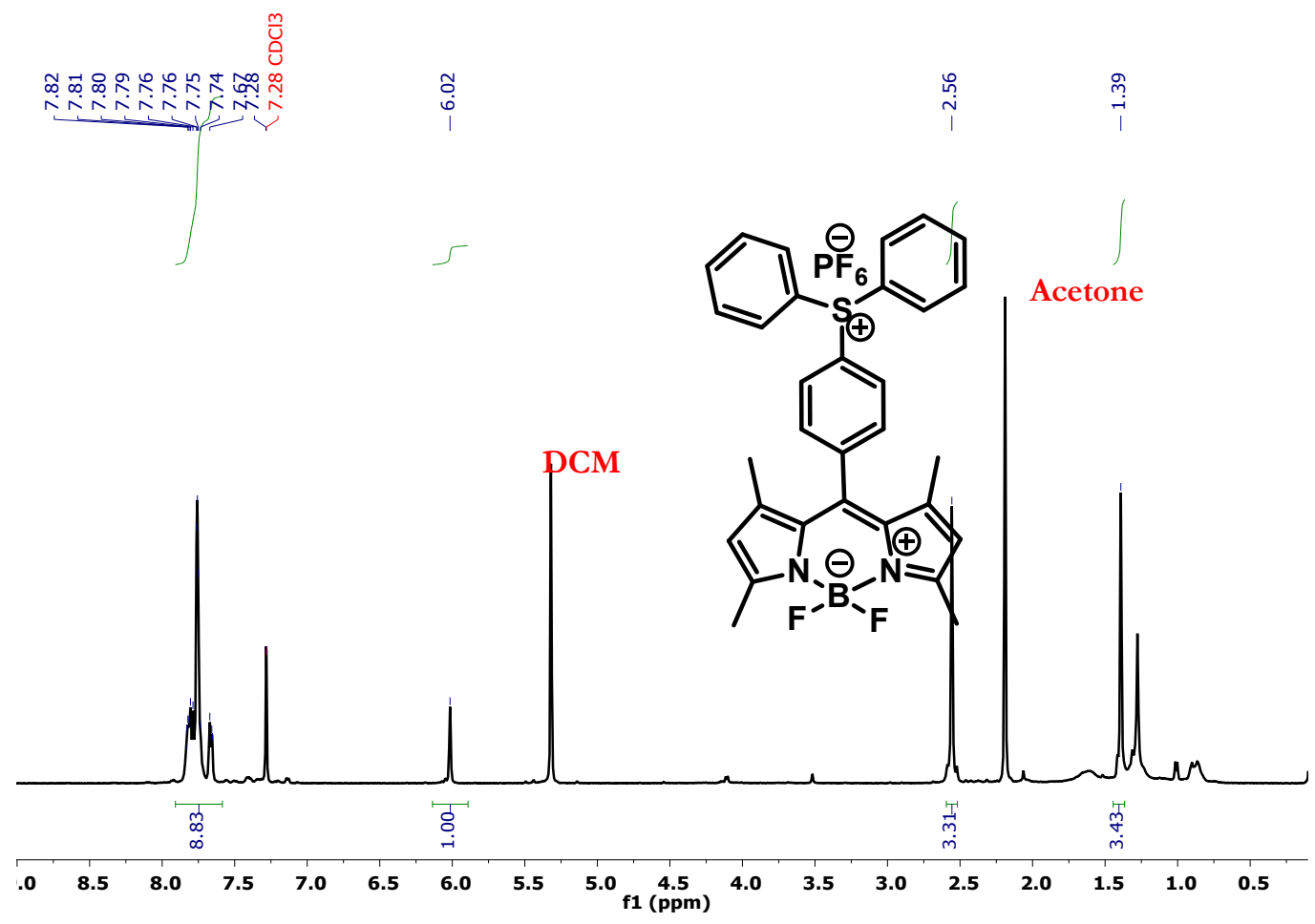

${ }^{1} \mathrm{H}$ NMR of PAG-1 

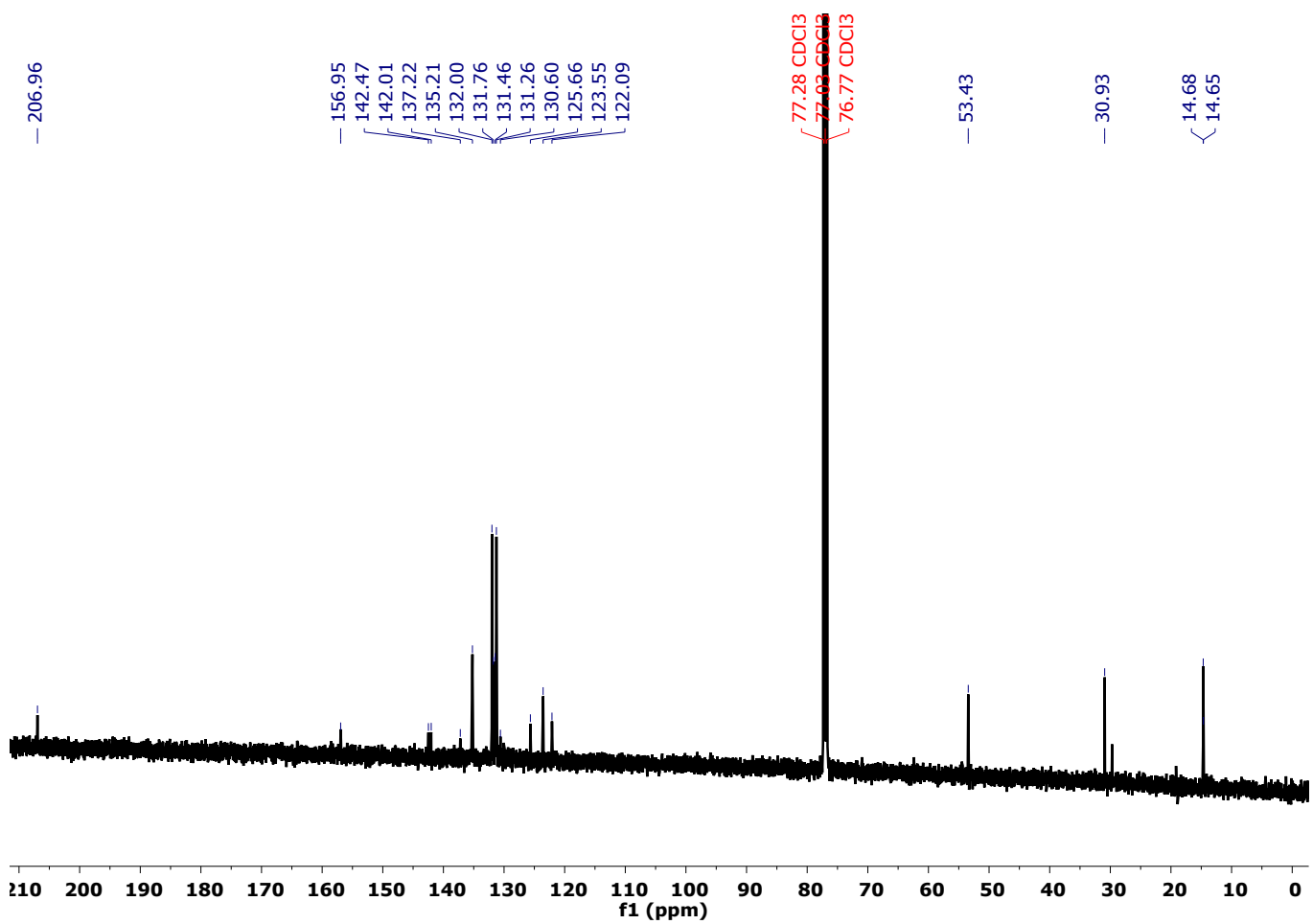

${ }^{13}$ C NMR of PAG-1

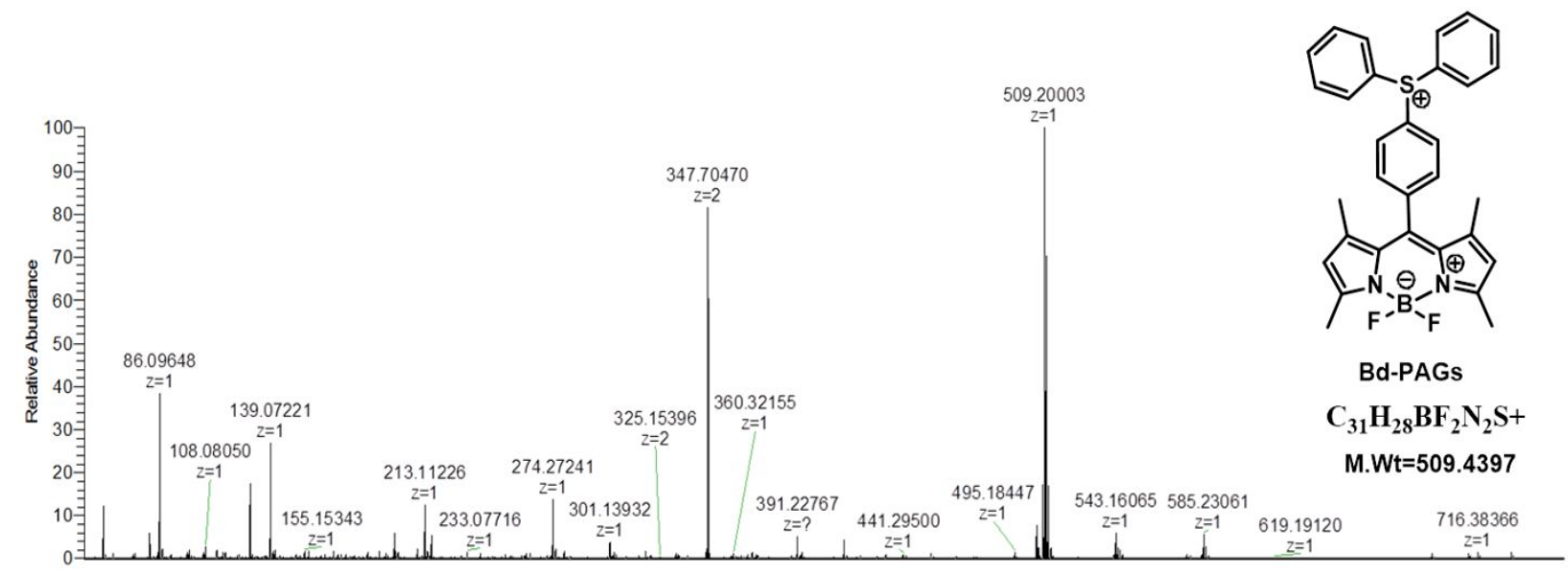

Mass spectrum of PAG-1 


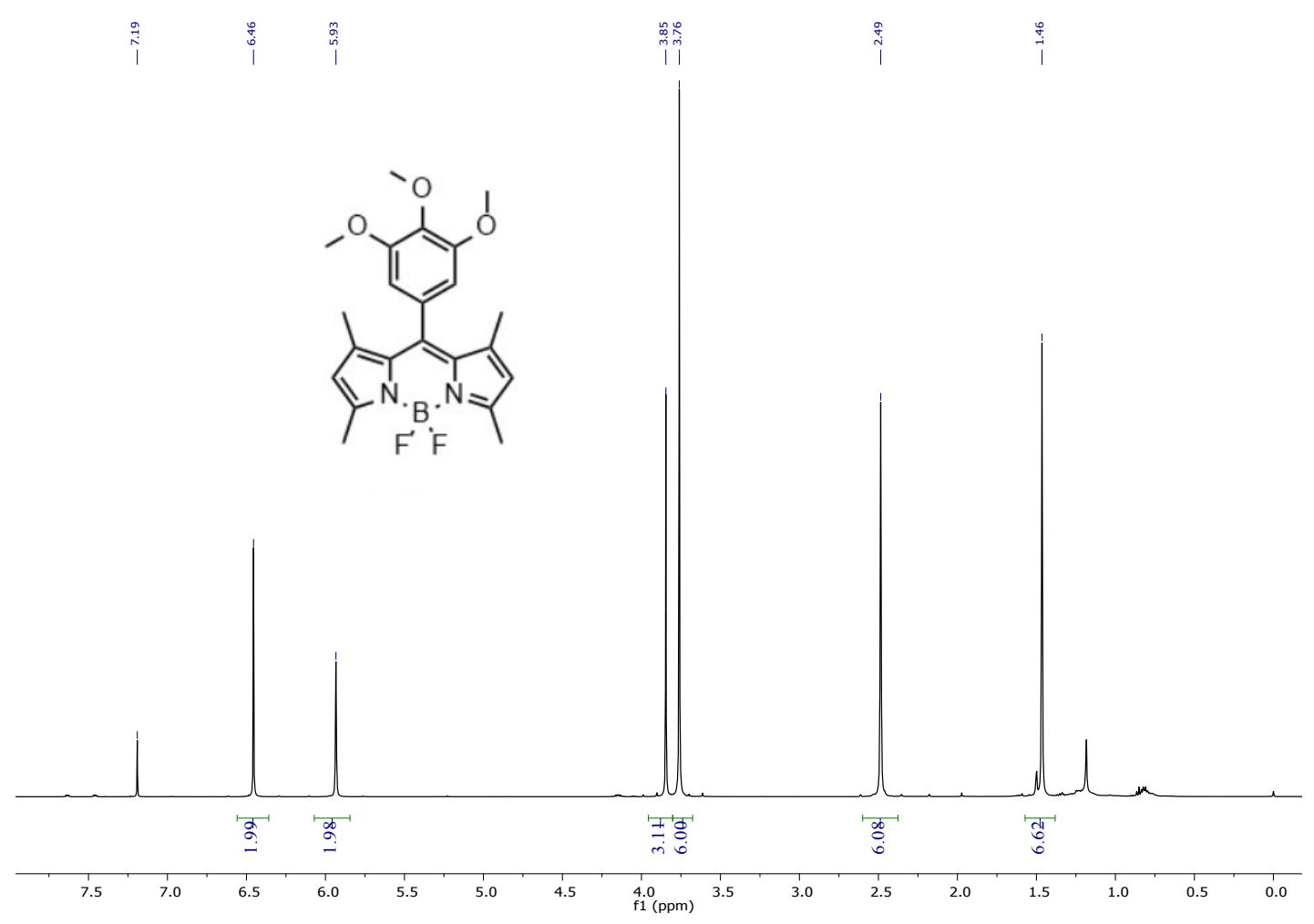

${ }^{1} \mathrm{H}$ NMR of compound (3)

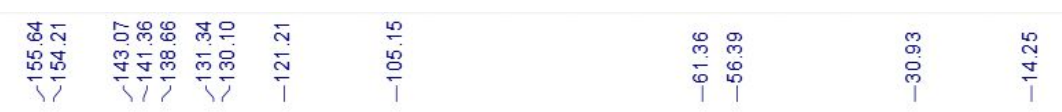<smiles>COc1cc(C2=C(c3c(C)cc(C)n3P)C(C)=CC2=O)cc(OC)c1OC</smiles>

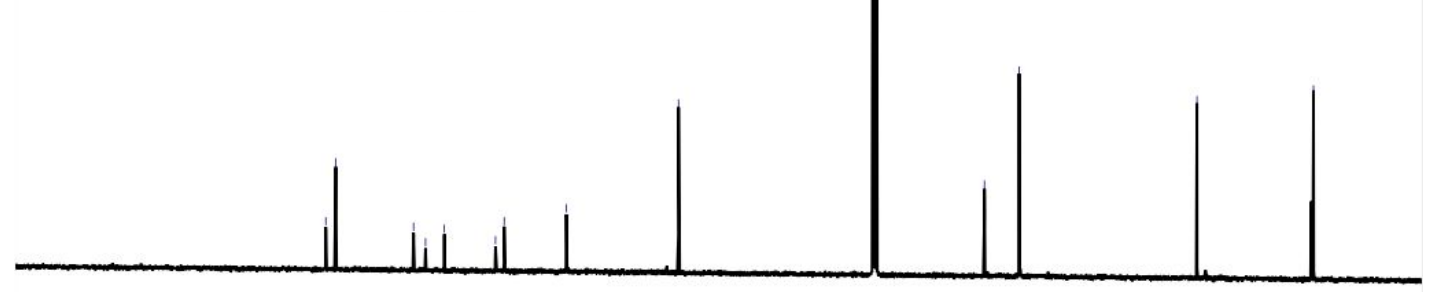

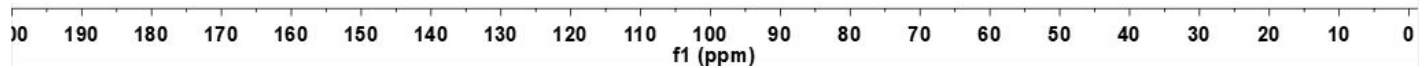

${ }^{13} \mathrm{C}$ NMR of compound (3) 


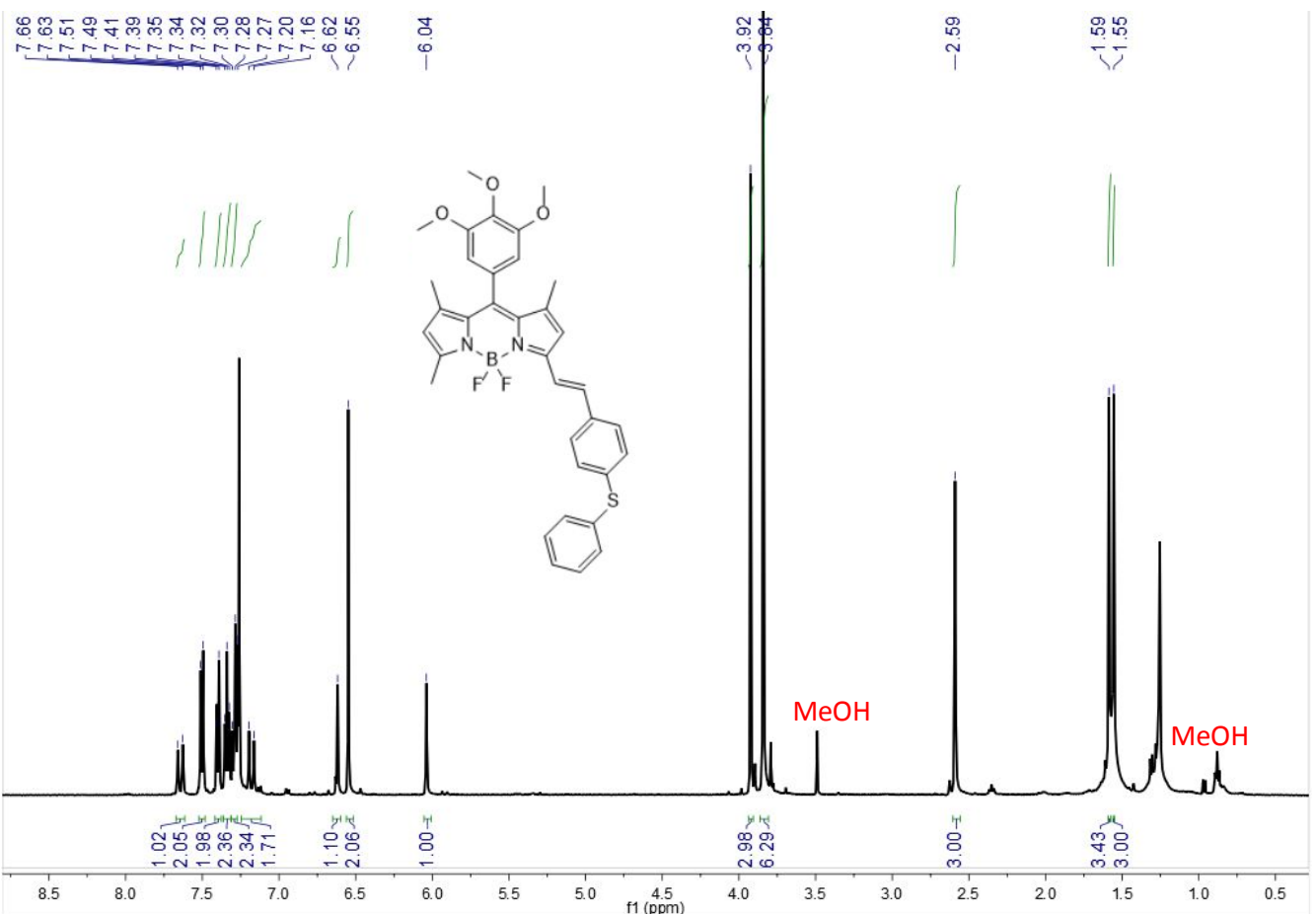

${ }^{1} \mathrm{H}$ NMR of 4-(phenylthio)styryl-BODIPY (4)
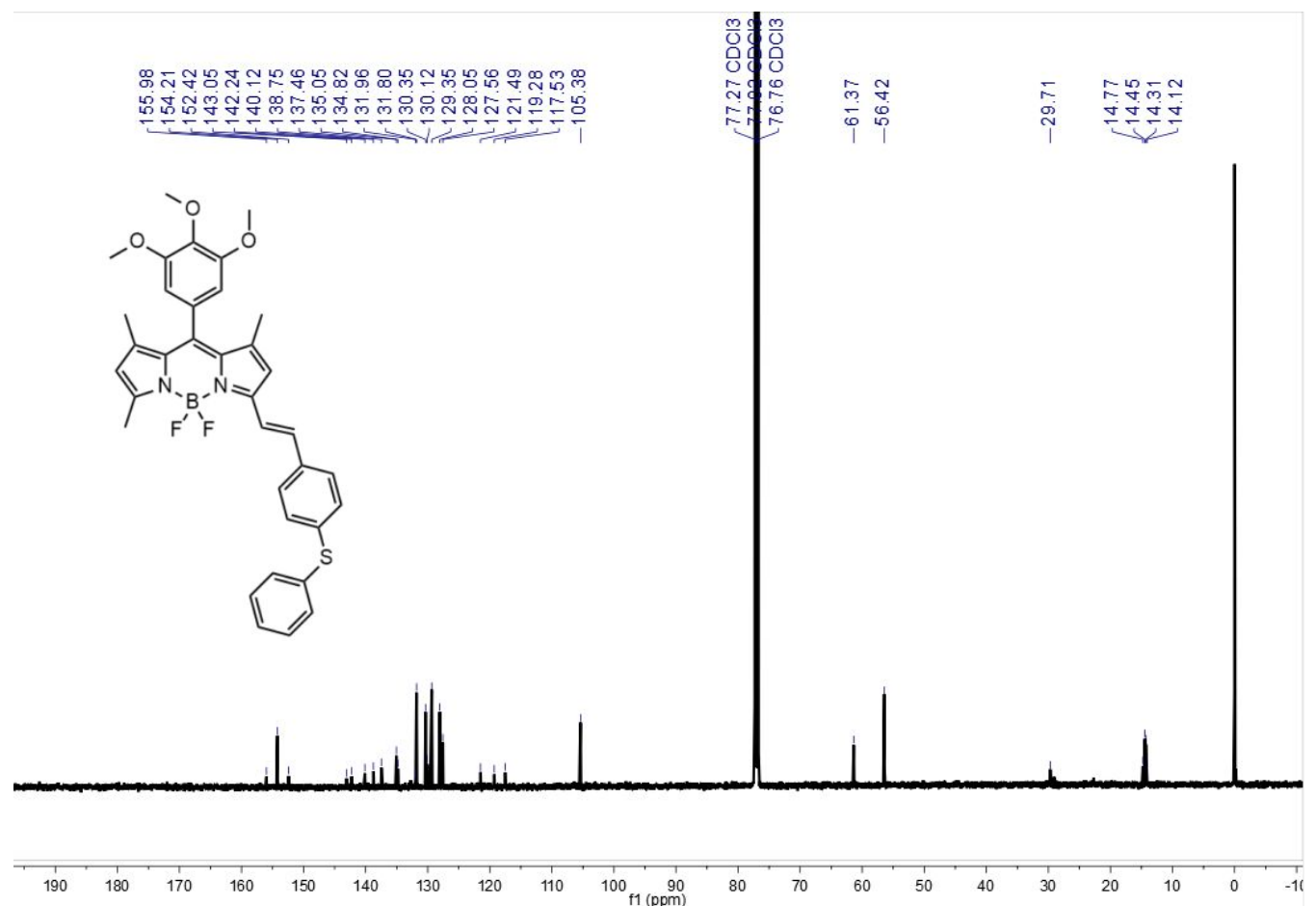

${ }^{13} \mathrm{C}$ NMR of 4-(phenylthio)styryl-BODIPY (4) 


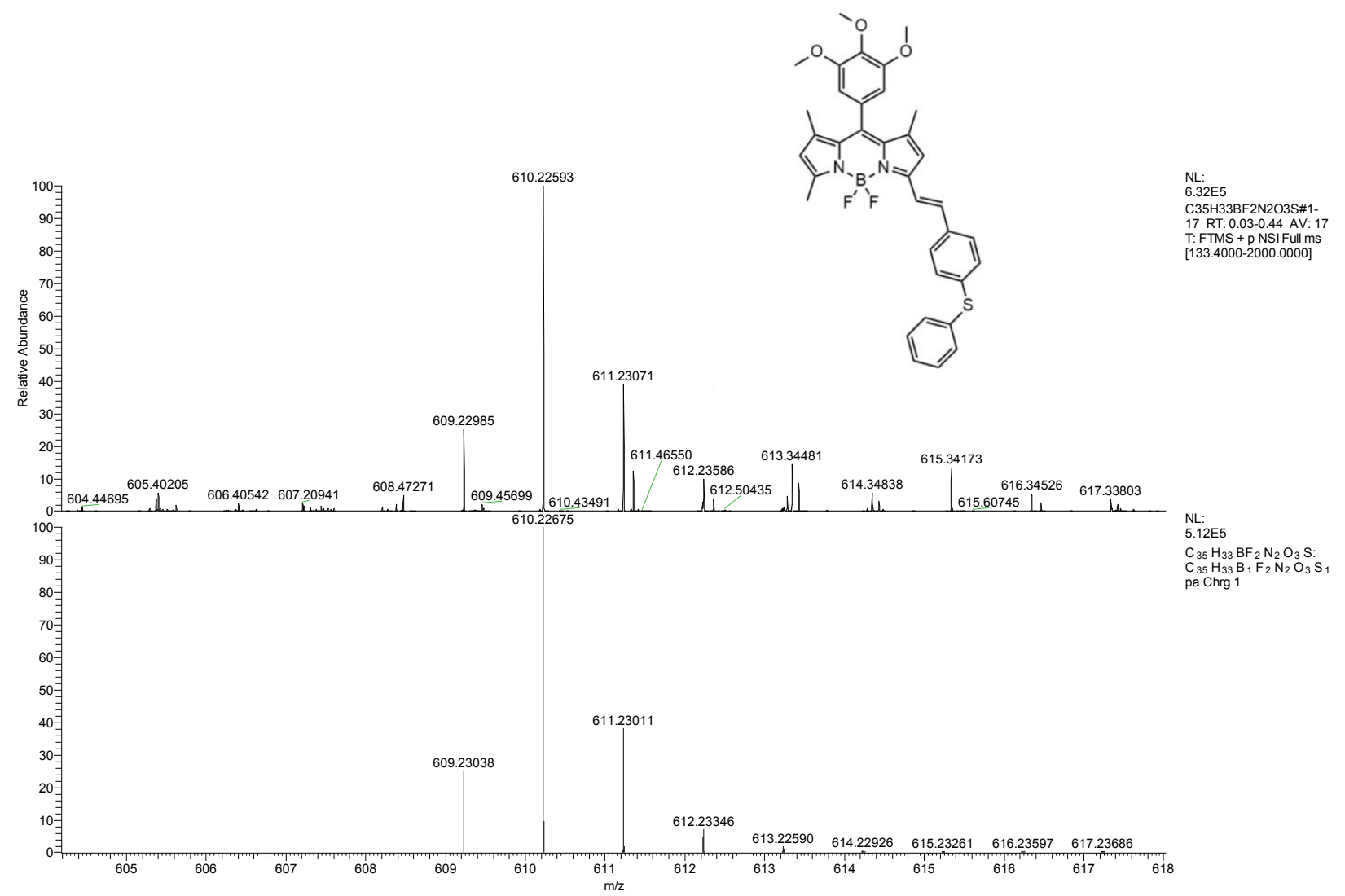

Mass spectrum of 4-(phenylthio)styryl-BODIPY (4)

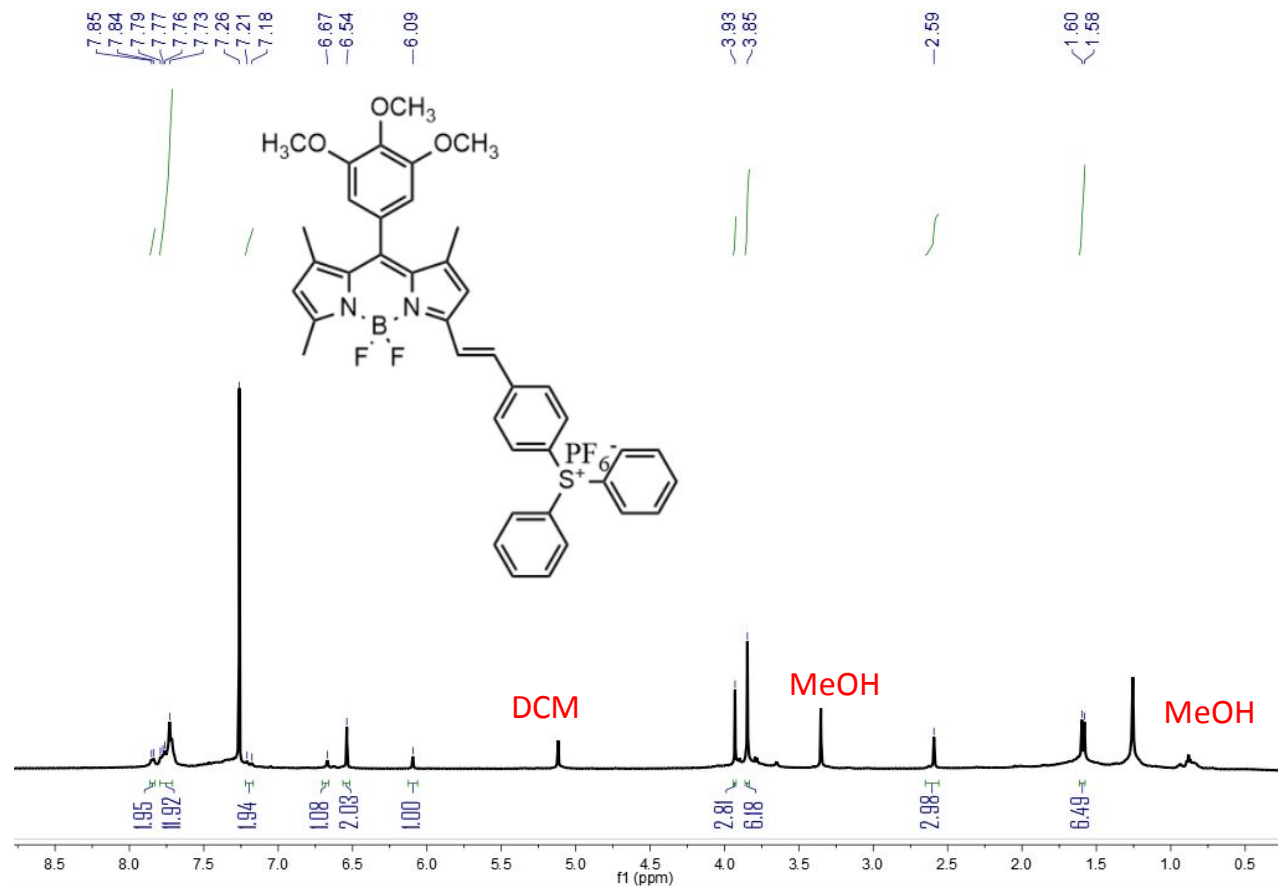

${ }^{1} \mathrm{H}$ NMR of PAG-2 

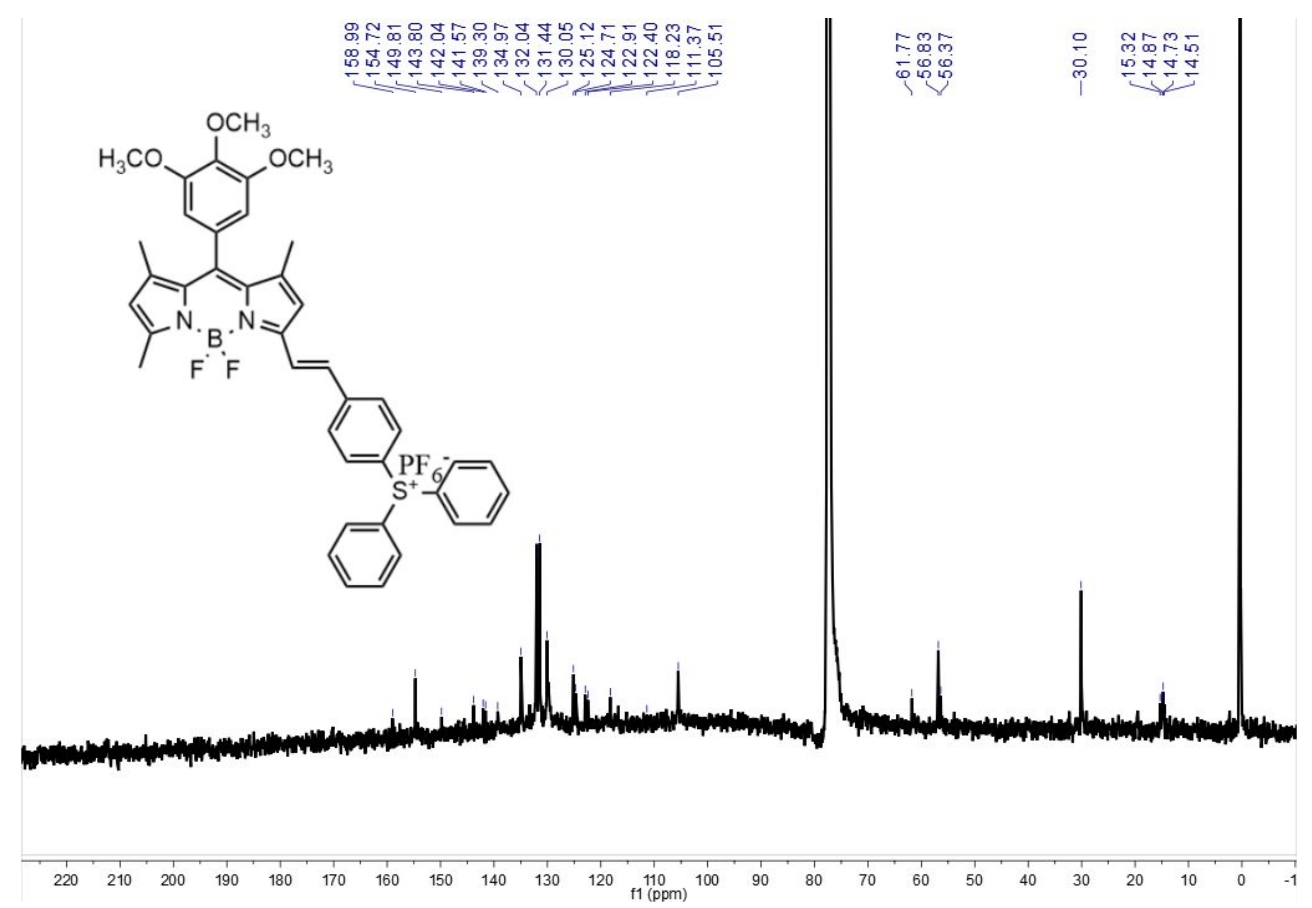

${ }^{13} \mathrm{C}$ NMR of PAG-2

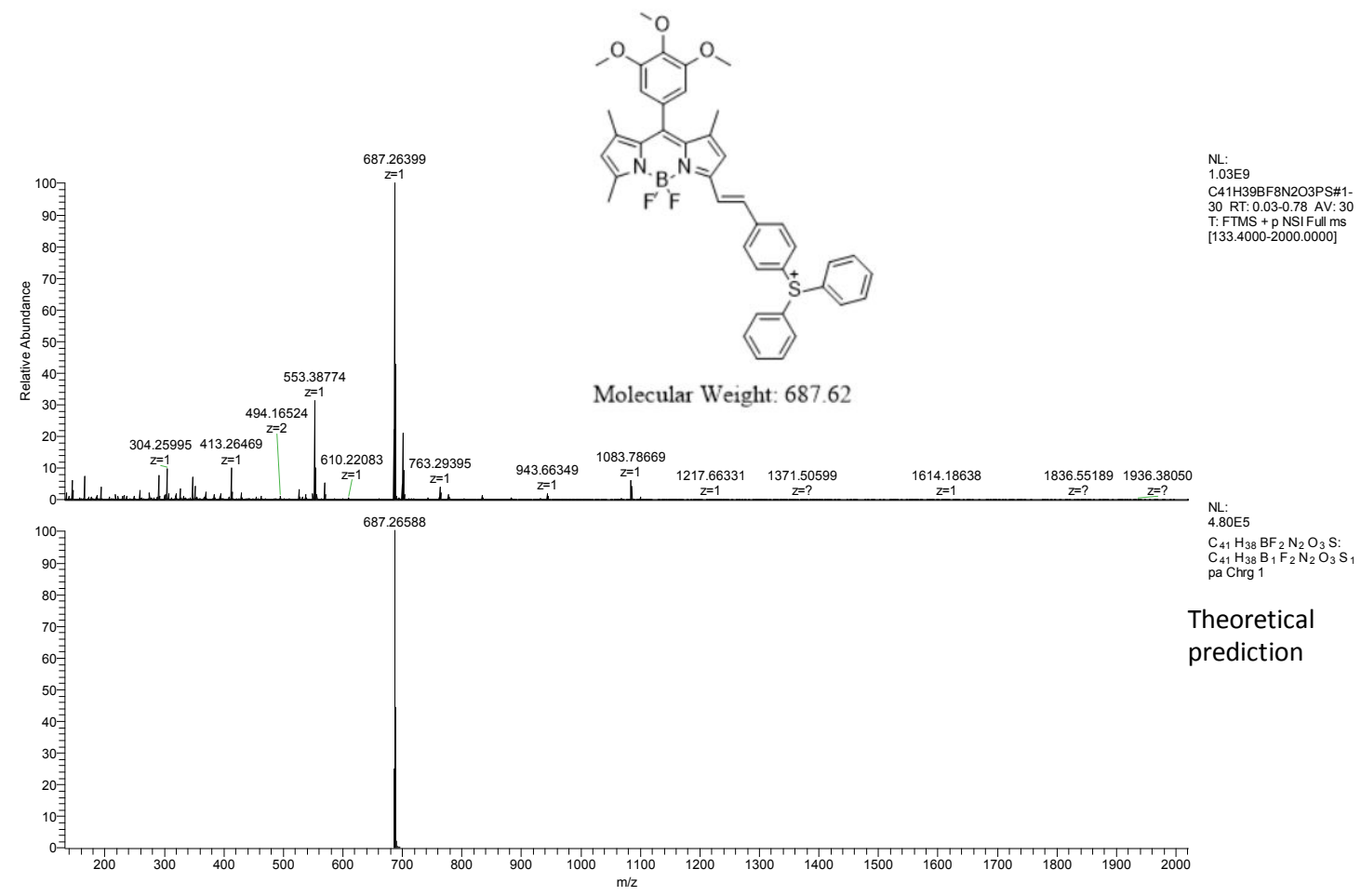

Mass spectrum of PAG-2 

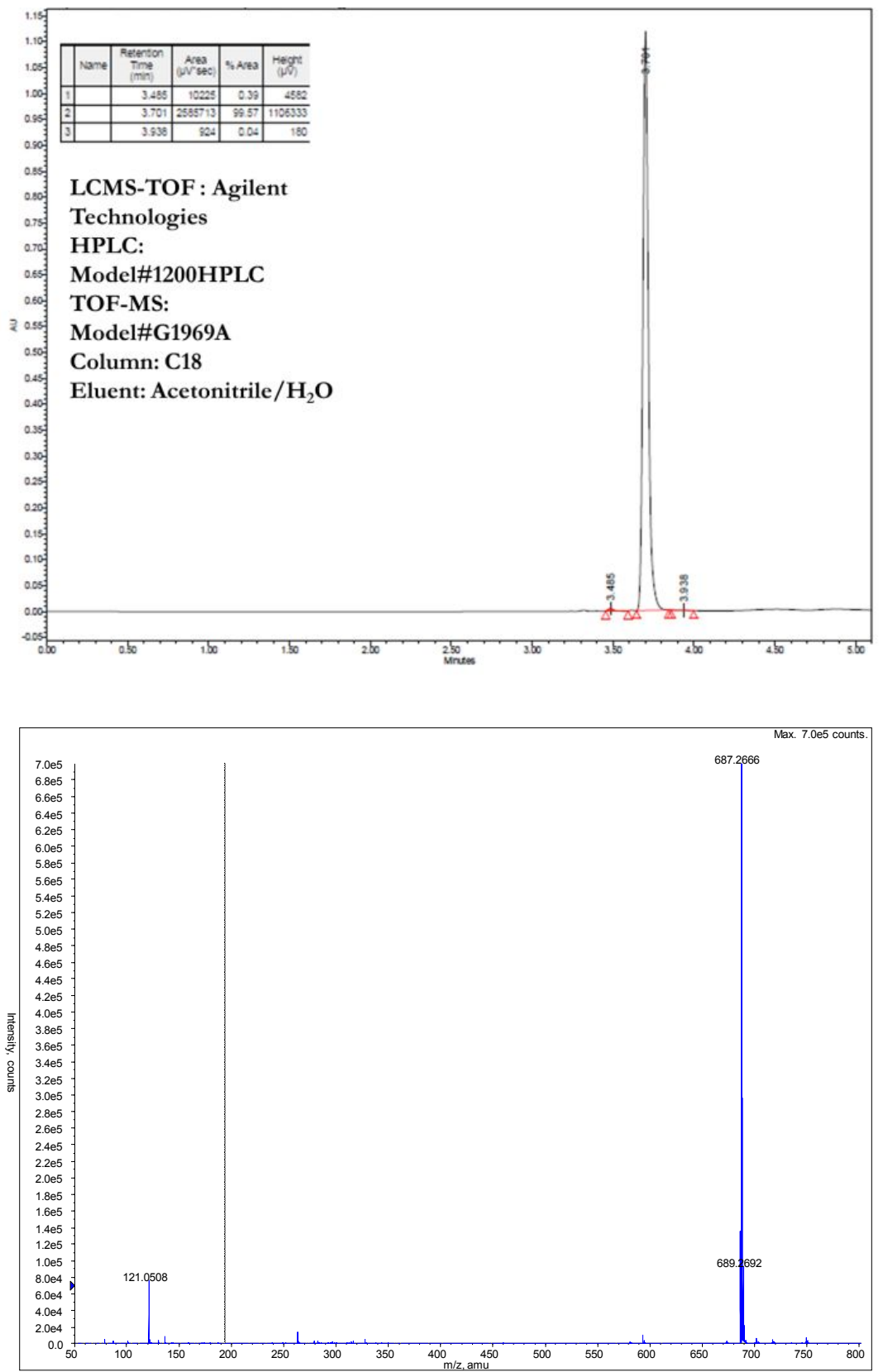

LCMS-TOF of PAG-2. 